\title{
The geological cycle of plastics and their use as a stratigraphic indicator of the Anthropocene
}

Jan Zalasiewicz ${ }^{a,}{ }^{,}$, Colin N. Waters ${ }^{b}$, Juliana Ivar do Sul c, Patricia L. Corcoran, ${ }^{d}$ Anthony D. Barnosky e, Alejandro Cearreta f, Matt Edgeworth g, Agnieszka Gałuszka h, Catherine Jeandel i, Reinhold Leinfelder j, J.R. McNeill k, Will Steffen l, Colin Summerhayes ${ }^{m}$, Michael Wagreich ${ }^{n}$, Mark Williams a, Alexander P. Wolfe ${ }^{\circ}$, Yasmin Yonan ${ }^{\text {a. }}$

Addresses:

a Department of Geology, University of Leicester, University Road, Leicester LE1 7RH, UK

b British Geological Survey, Keyworth, Nottingham NG12 5GG, UK

c Association of Polar Early Career Scientists (APECS-Brazil),

Rua Edgar Gerhke, Piratini, Sapucaia do Sul- RS. CEP 93216180

dDept. of Earth Sciences, University of Western Ontario, London, ON, Canada, N6A $5 B 7$

e.Dept. of Integrative Biology, Museum of Paleontology, Museum of Vertebrate Zoology, University of California, Berkeley, CA 94720, USA

${ }^{\mathrm{f}}$ Departamento de Estratigrafía y Paleontología, Facultad de Ciencia y Tecnología, Universidad del País Vasco UPV/EHU, Apartado 644, 48080 Bilbao, Spain.

g School of Archaeology and Ancient History, University of Leicester, University Road, Leicester LE1 7RH, UK

h Geochemistry and the Environment Division, Institute of Chemistry, Jan Kochanowski University, 15G Świętokrzyska St, 25-406 Kielce, Poland

${ }^{\text {i } L E G O S ~(C N R S / C N E S / I R D / U n i v e r s i t e ́ ~ P a u l ~ S a b a t i e r), ~} 14$ avenue Edouard Belin, 31400 Toulouse, France.

j Department of Geological Sciences, Freie Universität Berlin, Malteserstr. 74100/D, 12249 Berlin, Germany.

k Georgetown University, Washington DC, USA

${ }^{1}$ The Australian National University, Canberra ACT 0200, Australia.

m. Scott Polar Research Institute, Cambridge University, Lensfield Road, Cambridge CB2 1ER, UK. 
n Department of Geodynamics and Sedimentology, University of Vienna, A-1090

Vienna, Austria

o Department of Earth and Atmospheric Sciences, University of Alberta, Edmonton, AB T6G 2E3, Canada

*Corresponding author. Tel.: +4401162523928.

E-mail address: jaz1@le.ac.uk (J. Zalasiewicz)

\begin{abstract}
The rise of plastics since the mid-20th century, both as a material element of modern life and as a growing environmental pollutant, has been widely described. Their distribution in both the terrestrial and marine realms suggests that they are a key geological indicator of the Anthropocene, as a distinctive stratal component. Most immediately evident in terrestrial deposits, they are clearly becoming widespread in marine sedimentary deposits in both shallowand deep-water settings. They are abundant and widespread as macroscopic fragments and virtually ubiquitous as microplastic particles; these are dispersed by both physical and biological processes, not least via the food chain and the 'faecal express' route from surface to sea floor. Plastics are already widely dispersed in sedimentary deposits, and their amount seems likely to grow several-fold over the next few decades. They will continue to be input into the sedimentary cycle over coming millennia as temporary stores - landfill sites are eroded. Plastics already enable fine time resolution within Anthropocene deposits via the development of their different types and via the artefacts ('technofossils') they are moulded into, and many of these may have long-term preservation potential when buried in strata.
\end{abstract}

\title{
Keywords
}

Anthropocene, Plastics, Stratigraphy

\section{Introduction}

The concept of the Anthropocene, an epoch of time in which humans have come to dominate many surface geological processes, has been widely discussed since it was first proposed by Crutzen and Stoermer (2000) and Crutzen (2002). Sufficient evidence exists to suggest that the Anthropocene is a real geological phenomenon, with potential to be formalized within the Geological Time Scale (Zalasiewicz et al., 2008; Williams et al., 2011; Waters et al., 2014). Although many suggestions have been put forward regarding the timing of the Anthropocene, there is growing consensus that a starting time around the mid20th century and the post-WWII 'Great Acceleration' of population, industry and resource use (Steffen et al. 2007, 2015) is optimal. This is partly a result of the increase in scale of human impacts on the Earth system, such as the $\sim 120 \mathrm{ppm}$ rise in $\mathrm{CO}_{2}$ above pre-industrial levels, while the "Great Acceleration" interval is also marked by key, near-synchronous stratigraphic markers that enable the strata of a putative Anthropocene Epoch to be identified (Waters et al. 2016). These markers include artificial radionuclides (Hancock et al., 2014; Zalasiewicz et al., 2015; Waters et al., 2015), aluminium metal (Zalasiewicz et al., 2014), fly 
ash particles (Rose, 2015; Swindles et al., 2015), persistent organic pollutants (Muir and Rose, 2007) and a variety of biological indicators (Barnosky, 2014; Wilkinson et al., 2014).

One further potential indicator is plastic, as this material has been manufactured in abundance since the mid-20 ${ }^{\text {th }}$ century. Plastics are key to the momentum of the technological revolution from the start of the 'Great Acceleration', because of their remarkable utility and versatility. They are fundamental to contemporary hygiene, as wrapping for foodstuffs and other materials, as disposable gloves, coats and medicine encapsulations used in hospitals, and in providing inexpensive clean water systems via water bottles and pipelines. Plastics are also components of many of our buildings, tools and machines.

Although now indispensible, plastics are easily disposable. Discarded in various ways after use, we see them widely around us as litter. The scope and range of plastic contamination has become increasingly apparent over the last few decades, and it is now regarded as a major, and growing, environmental hazard (see below). A corollary of this dispersal is that plastics might be used as markers of the age and character of the sedimentary deposits that they are buried in, much in the way that geologists use fossils to characterize and date strata. It is this potential that we explore in this paper.

Plastics are relatively easily recognizable, without the need for sophisticated analytical equipment, as is the case for the detection of radionuclides. They may, therefore, be widely effective stratigraphic markers for Anthropocene strata. However, appreciation of their utility requires consideration of their behavior as a geological material, rather than as a product of material science, or as an environmental pollutant. This idea of plastics as a significant component of the present-day sedimentary cycle is growing, although clear and detailed global characterization of this concept has only just begun (e.g. Reed, 2015; Corcoran 2015).

This paper thus places current knowledge about the environmental behavior of plastics into a general geological perspective. We consider the extent to which plastics may provide a pragmatic stratigraphic marker, not just in soils and other terrestrial deposits, but also far into the marine realm. We develop this analysis to provide the first predictive model of the transport, distribution and burial of plastics as sedimentary particles in a representative array of global sedimentological settings, both terrestrial and marine. We also consider the factors affecting the long-term preservation of plastics once buried in geological strata. Plastics, seen through this prism, may range more widely through time and space than can be seen by the casual eye.

\section{The nature and production of plastics}

Plastics are malleable solids made of high molecular weight organic polymers. Most are entirely synthetic - primarily made from petrochemicals - although some are cellulose-based. The first plastics to become commonly used were 
permanently hard and brittle, such as shellac, for gramophone records from the late 19th century, and bakelite, produced widely from the 1920s to the 1940s and still in minor use today (Albus et al., 2006). Viscose silk and rayon, made from a cellulose base, have been manufactured since the early $20^{\text {th }}$ century, and remain in production. Nylon, polystyrene (PS), polyvinyl chloride (PVC), polyethylene (PE) and polytetrafluoroethylene (PTFE) began to be produced in the late 1930s and 1940s, polypropylene (PP) and expanded polystyrene foam in the 1950s, and polyethylene terephthalate (PET), from which most containers and bottles are now made, was patented in 1973 (Fig. 1). Development continues to this day, with some 15-20 main groups of plastic (Shah et al., 2008). 


\section{Material}

Gutta percha

Parkesine

Year C.E.

Celluloid

Shellac gramophone records

Viscose silk/rayon

Bakelite

Scotch Tape

Vinyl LPs

Polyethylene

Nylon

Cellulose acetate cigarette filters

PVC water pipes

Commercial polystyrene

LDPE bottles

Formica

Velcro

Plastic credit cards

Polyethylene bags

Commercial polyester fibres

Expanded polystyrene

Polypropylene

Polycarbonates

Lego

PET bottles

uPVC windows

Compact discs
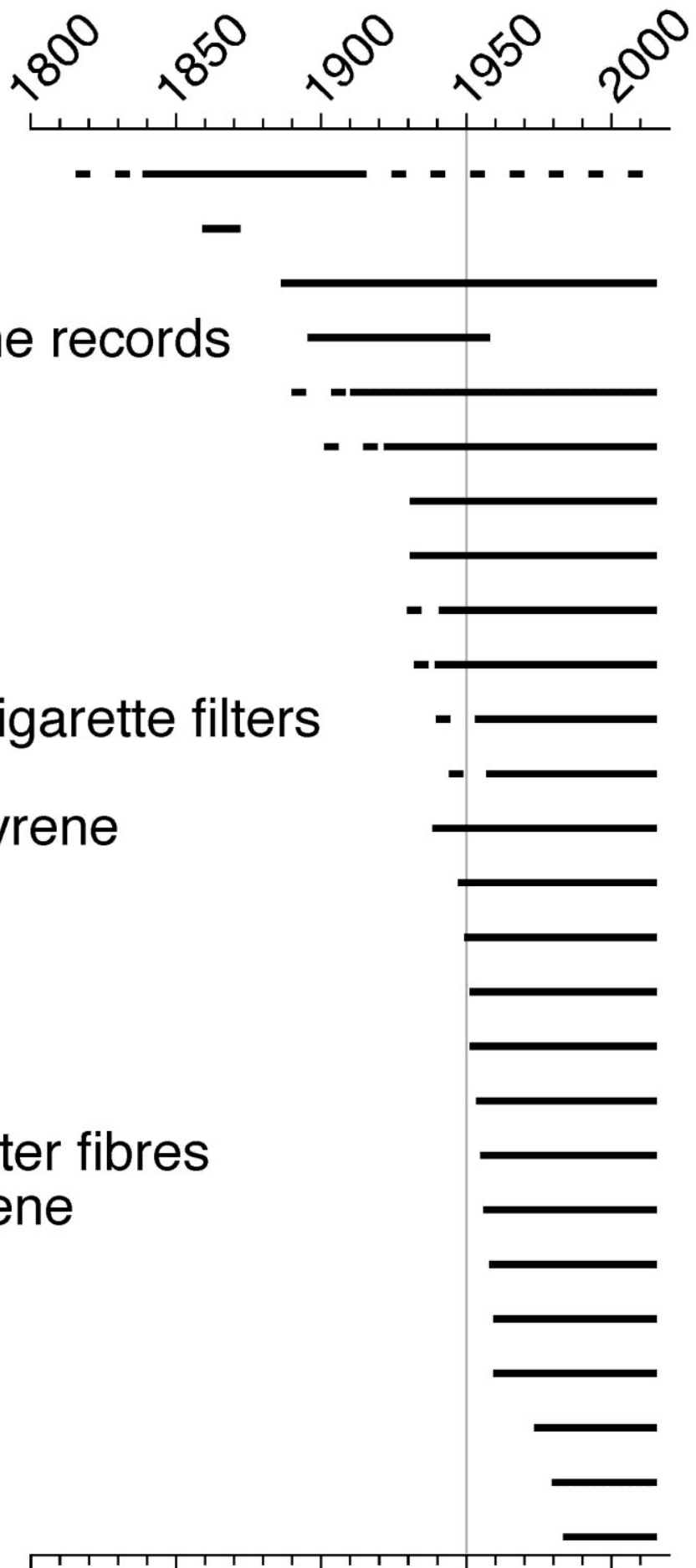

Fig. 1. Stratigraphic appearance of some major types of plastics and plastic artefacts. Gutta-percha, the hardened sap of any of eight tree species from southeast Asia, is not strictly a plastic. Nevertheless, it features in some early histories of this material. Between 1850 and 1899, some 27,000 tons were laid on the seafloor to serve as insulation for telegraph cables due to its resistance to saltwater corrosion (Tully, 2009). Adapted from information mostly in http://www.bpf.co.uk/Plastipedia/Plastics History/Default.aspx. 
The extraordinary global expansion of this now indispensible material (Andrady and Neal, 2009) can be seen in the dramatic rise of produced plastics, from the less than 2 million tonnes manufactured in 1950 to the 300 million tonnes made annually today (Fig. 2). The cumulative amount produced as of 2015 is of the order of 5 billion tons, which is enough to wrap the Earth in a layer of clingfilm, or plastic wrap. The current global annual production represents $\sim 40 \mathrm{~kg}$ of plastics produced annually for each of the 7 billion humans on the planet, approximating the total human biomass (Zettler et al., 2013). The amount projected by 2050 , on current trends, is about 40 billion tons (Rochman et al., 2013), which is enough to wrap 6 layers of clingfilm around the planet. It is an enormous industry, currently using approximately $8 \%$ of global oil extraction for its manufacture (Thompson et al., 2009). Approximately $4 \%$ is used as a source material for the plastics, and $4 \%$ is used to provide the energy to produce the plastics: http://www.wastewatch.org.uk/data/files/resources/13/Plasticsinformation-sheet-FINAL-Oct-08.pdf ).

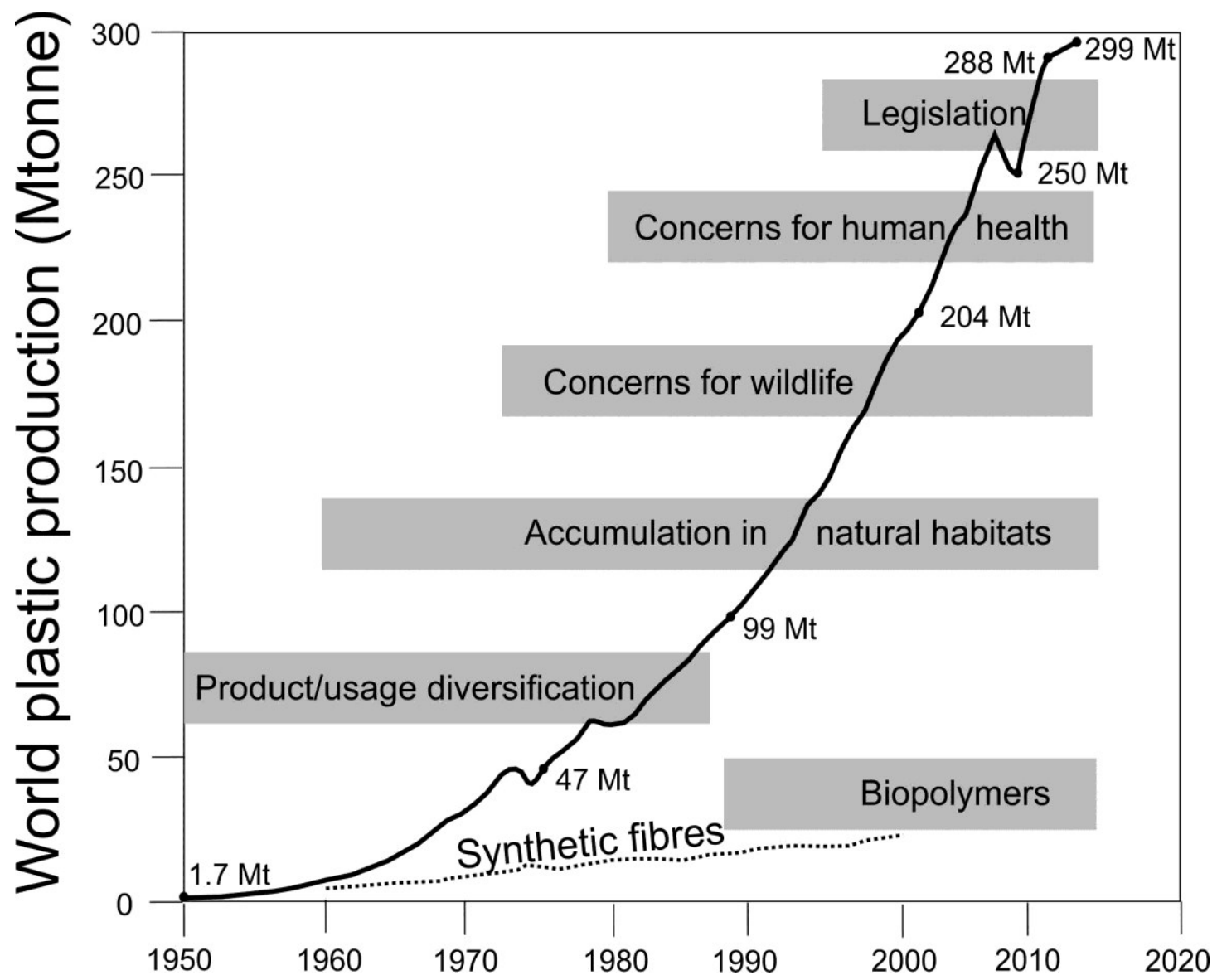

Fig. 2. Growth of plastics production: from PlasticsEurope $(2013,2015)$. Synthetic fibres production (metric tons per year) from Thompson et al. (2004) and historical stages in plastics development, in grey boxes, from Thompson et al. (2009).

Most of the global plastics that have been produced are still present in the environment. Of the plastics produced in Europe, about half are accounted for by 
recycling, energy recovery (i.e. incineration) and landfill, with the proportions incinerated and put into landfill varying greatly from country to country (PlasticsEurope, 2013, 2015). The proportion recycled, within the half that is accounted for, is typically 15-25\% in Europe (op. cit.), but figures provided by Barnes et al. (2009) for the USA suggest recycling rates there are below 5\%. The half of plastics production that is not accounted for (see also Rochman et al., 2013) presumably stays in the environment, either as components of some 'permanent' object or is disposed of otherwise, including casually as litter.

\section{Plastics in the environment}

Plastics are useful to humans because they are light, strong, flexible and relatively inert. They are insoluble in water, and resistant to biological decay and much chemical attack, over decades to centuries at least. They are easily transported by wind (Gasperi et al. 2015) and water through the environment, where they may accumulate. Plastics are proving to be much more mobile than other human-made materials such as ceramics or glass. It took ceramics thousands of years to achieve anything resembling a global distribution, and they are distributed mainly in terrestrial deposits, with very little incursion into marine environments (Edgeworth et al., 2015). From being a local 'litter' problem a few decades ago, plastics are increasingly recognized as a major environmental problem on land and in the sea. In response, there has been a rapidly expanding body of literature on the subject within the last few years (e.g. Ivar do Sul and Costa, 2014).

Plastics in the environment are divided broadly into macroplastics and microplastics. Macroplastics are $>5 \mathrm{~mm}$, and include everything that we would recognize as litter, such as plastic bags and bottles, discarded fishing nets, plastic toys, and sections of plastic piping (Fig. 3). In some surveys, for instance by cameras on remotely operated submarine vehicles, macroplastics are the only plastics that can be observed (Watters et al., 2010; Richards and Beger, 2011). 


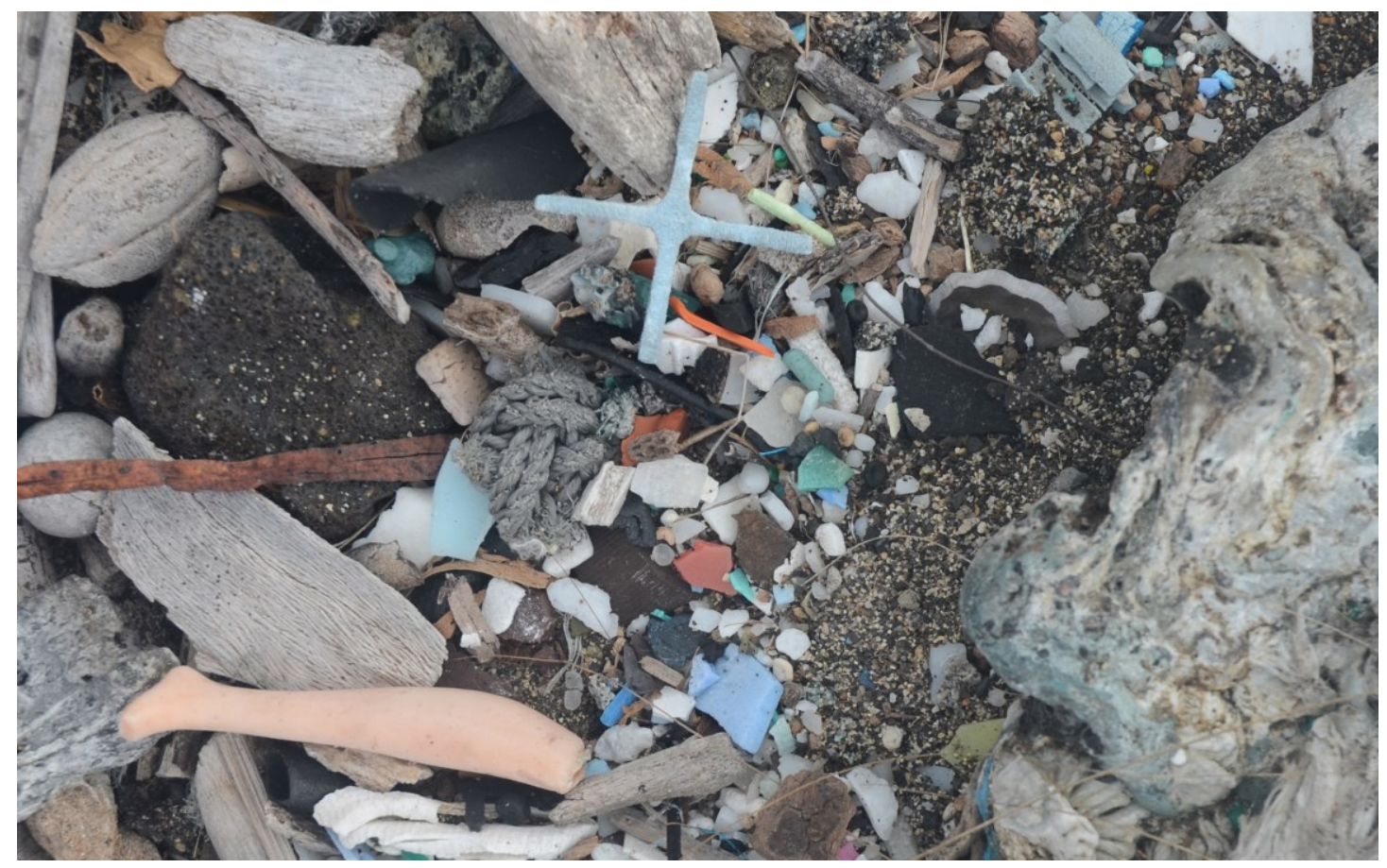

Fig. 3. Plastic debris on Kamilo Beach, Hawaii (item on right of photo is plastiglomerate); Field of view is $20 \mathrm{~cm}$ across (Photo: P. Corcoran).

Microplastics $(<5 \mathrm{~mm})$ are commonly invisible to the naked eye, particularly when mixed into sediment. Some microplastics are of their original size, such as the 10-1000 $\mu \mathrm{m}$ plastic microbeads (polyethylene microspheres that are put into certain cosmetics, facial scrubs and toothpaste) as well as lentil-sized resin pellets ("nurdles") that are the raw materials for plastic products. Other microplastics have been physically or physico-chemically degraded. A microplastic category recently recognized as important is plastic fibres $(\sim 0.1$ $\mathrm{mm}$ across and usually up to 2-3 $\mathrm{mm}$ long), detached from synthetic fabrics during washing. A single synthetic garment, for instance, can release over a thousand fibres in a single wash cycle (Fig. 4). Too small to be filtered out either by machine or sewage plant, these can travel far by river and sea current, and become deposited in sediment layers (Browne et al., 2010, 2011; Woodall et al., 2014). 


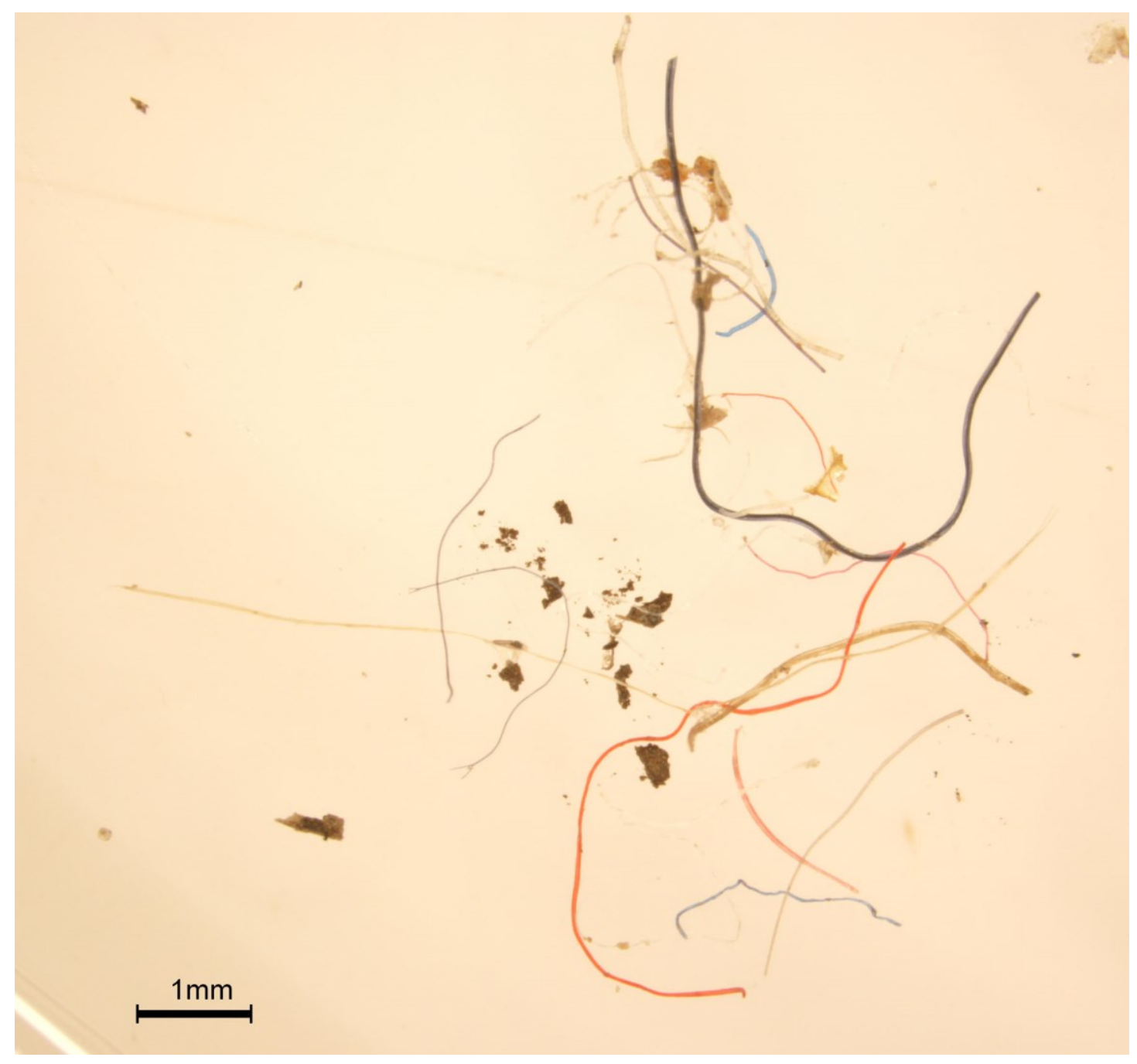

Fig. 4. Microplastic fibres found in bottom sediments of Lake Ontario - sampled by glew corer (Photo: Anika Ballent).

Plastics can be considered sedimentary components in both terrestrial and marine environments; however, their distribution on land appears to have had much less study than that in the sea (Thompson et al., 2009; Rillig, 2012). This may be a result of the greater heterogeneity of landscape, both natural and anthropogenic, which makes analysis difficult. Nevertheless, it is clear even by casual observation that macroplastic debris may be found in most inhabited environments. Microplastics are not easily visible, but methods for their analysis in the environment have been developed. They can be extracted from water by filtering, and separated from sediment via sieving or density separation using centrifuge and salt solutions (Nuelle et al., 2014; Woodall et al., 2014; Corcoran et al., 2015).

Nanoplastics are particles that are typically tens of nanometers in diameter. These may be produced intentionally, for example for drug delivery, detergents or cosmetic use, or they may result from fragmentation of larger plastic particles. Studies of nanoplastics have indicated their large surface-to-volume ratio, which increases their capacity to adsorb organic compounds, potentially gives an 
ability to penetrate cell walls, and they have been shown to affect the growth and reproduction of at least some aquatic invertebrates (e.g. Besseling et al., 2014; Della Torre et al., 2014; Velzboer et al., 2014). The distribution of nanoplastic particles in the natural environment is very poorly known because of the technical difficulty of isolating them from water or sediments, but they are almost certainly becoming increasingly commonly dispersed.

\section{Land}

On land and away from shorelines, plastic litter is widely distributed in the surface environment, most clearly in and around urban areas via casual littering. However, its distribution seems to have had little detailed study (Thompson et al., 2009; Rillig, 2012). The use of plastics in agriculture has grown since the 1960s, and Hussain and Hamid (2003) noted that global agricultural consumption of plastics is $\sim 2.5$ million tons per year. They are used in transplant and bedding plant production, as irrigation tape, trays and pots, tunnels, hay bale wraps, and in greenhouse construction. Plastics may become incorporated into cultivated soils, where they become thoroughly mixed with other materials to the full depth of ploughing.

The stratigraphic distribution of plastics below the ground surface correlates strongly with the distribution of landfill sites, where plastics in the last few decades have come to make up approximately $10 \%$ by weight of the waste buried (Thompson et al., 2009). Where landfill sites have been mapped out and their operation dated, sedimentary deposits up to several tens of metres thick with concentrations of plastics may be delineated (Figs. 5, 6). In 1967, in the UK, plastics formed about 3\% of municipal landfill waste (Bridgewater, 1986).

However, increasing production of plastics in the 1960s coincided with increased casual disposal of single-use goods rather than re-use and repair. This contributed to the rapid increase in the proportion of plastics in landfill in the 1970s (Ford et al., 2014, fig. 11). Subsequent legislation across many parts of the world has stimulated increasing reuse and recycling of plastic goods, such as supermarket plastic bags, but at best this has restricted rather than overturned the relentless growth of plastic disposal. The problem is greater in some developing countries where the arrival of abundant packaged goods is associated with inefficient waste disposal.

The distribution of landfill sites commonly coincides with the (former) outcrop of bulk minerals, such as quarries for aggregate and for brick clay. Landfill sites, especially modern ones with leak-proof seals, tend to mummify material - even paper and foodstuffs - rather than encourage it to decay (Rathje and Murphy, 1992). Hence, plastics may be expected to survive even longer in landfills than at the surface (cf. Tansel and Yildiz, 2011), with the potential to become fossilized or reworked by future erosion (see Discussion below). 


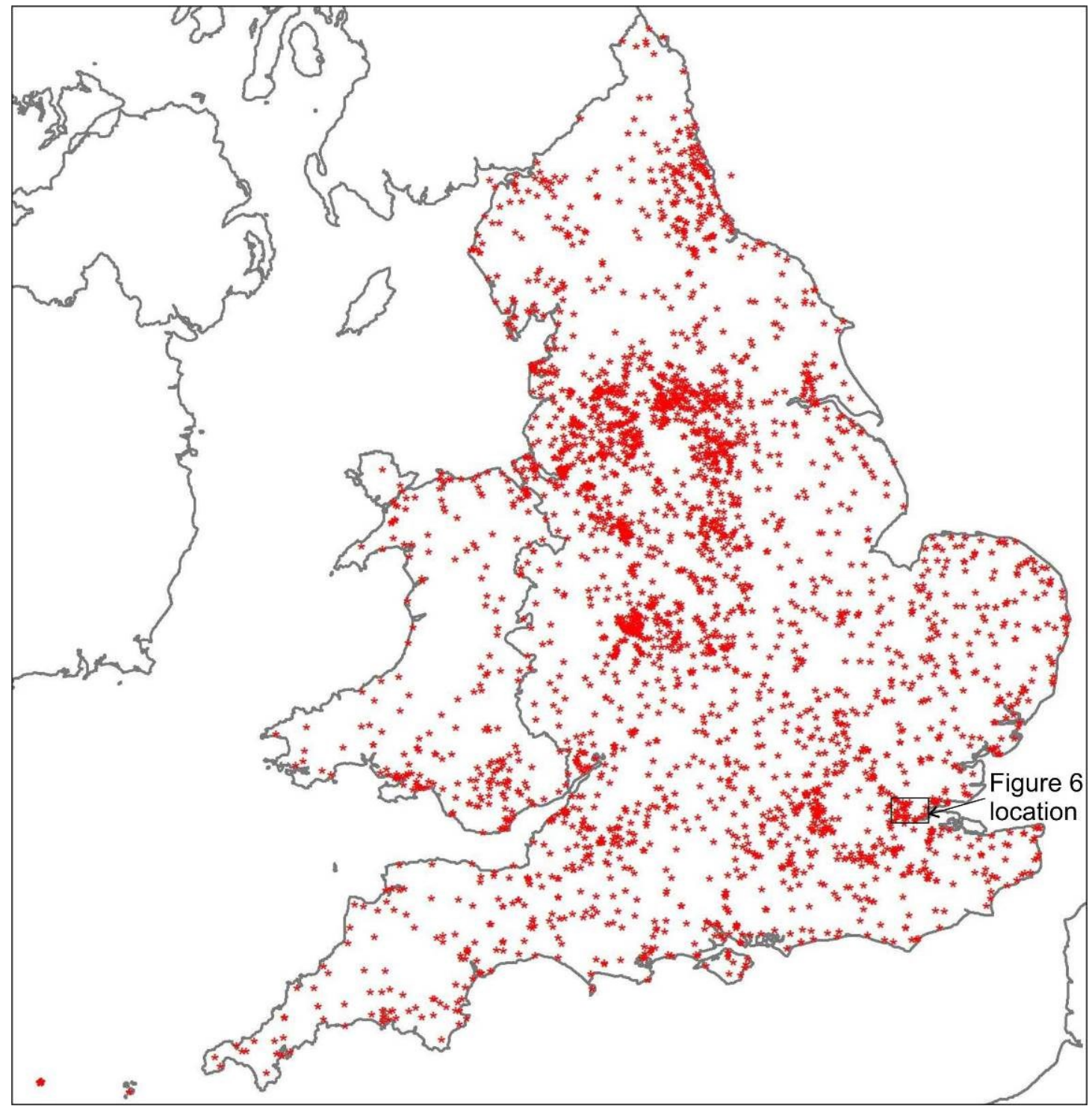

Fig. 5. Distribution of 3055 waste disposal sites across England and Wales active during the period 1971-3 (source: British Geological Survey database, held on behalf of Department of Environment). Box shows location of Fig. 6. BGS CNERC 2015. All rights reserved. 


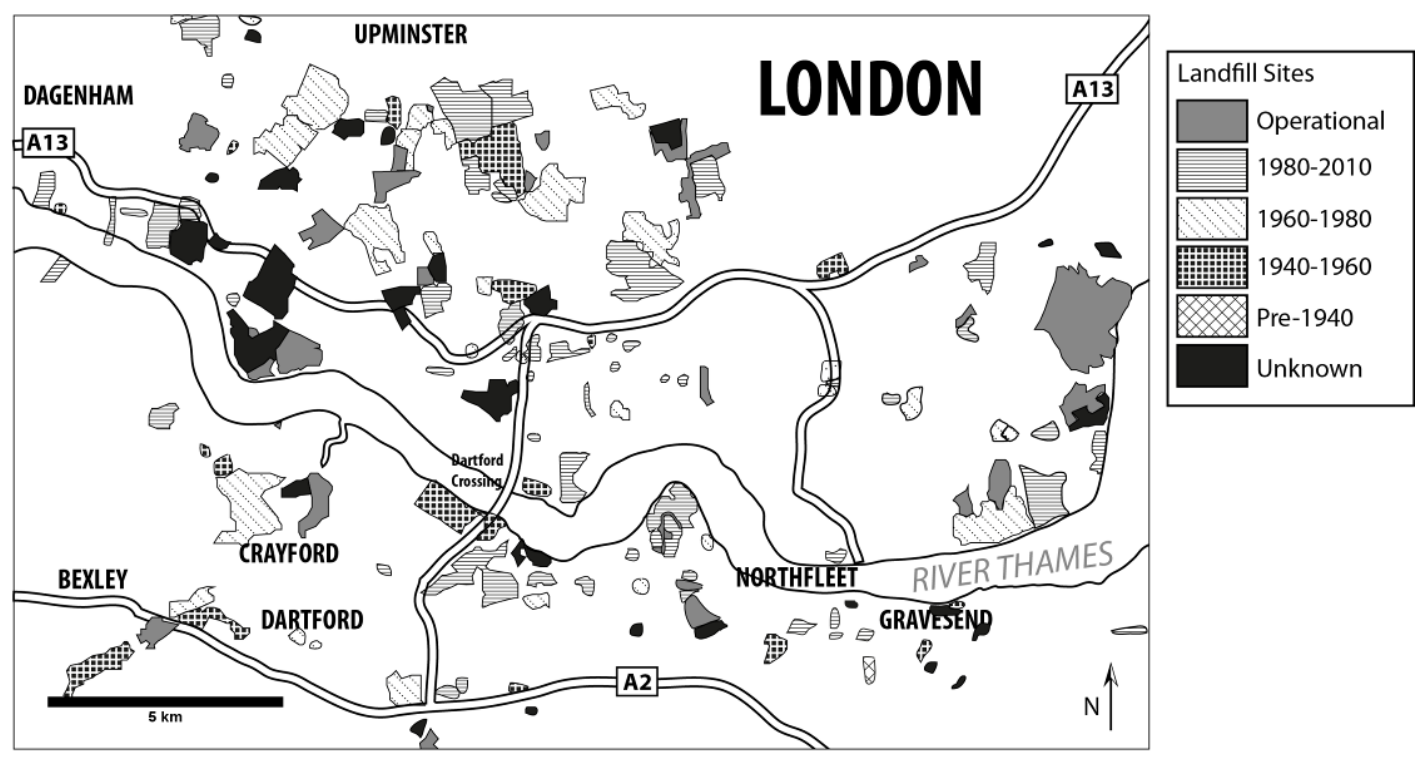

Fig. 6. Landfill locations in part of east London, showing operational history; post-1960 sites generally include significant plastics content (from Environment Agency data).

Road networks have increasingly become corridors of plastic deposition, partly through surface deposition of discarded material, where plastics are likely to degrade or be dispersed relatively quickly and not accumulate as substantial deposits. Nevertheless, these are likely to be zones of microplastics production through degradation and fragmentation. Plastics are also widely used in the laying of cables and pipes for services and communications, which are deliberately buried in backfilled trenches, often under or along roads.

Plastics are already widely used as stratigraphic markers in field archaeological practice - as indicators of modern or recently disturbed deposits (Fig. 7). Even small amounts of plastic found as inclusions within a layer can be used as evidence of date of deposition. This can provide precise constraints on the age of the specific deposit within which it is found, and also confers relative dating information on layers that are stratigraphically above ('later than') and below ('earlier than') the plastics-bearing layer.. 


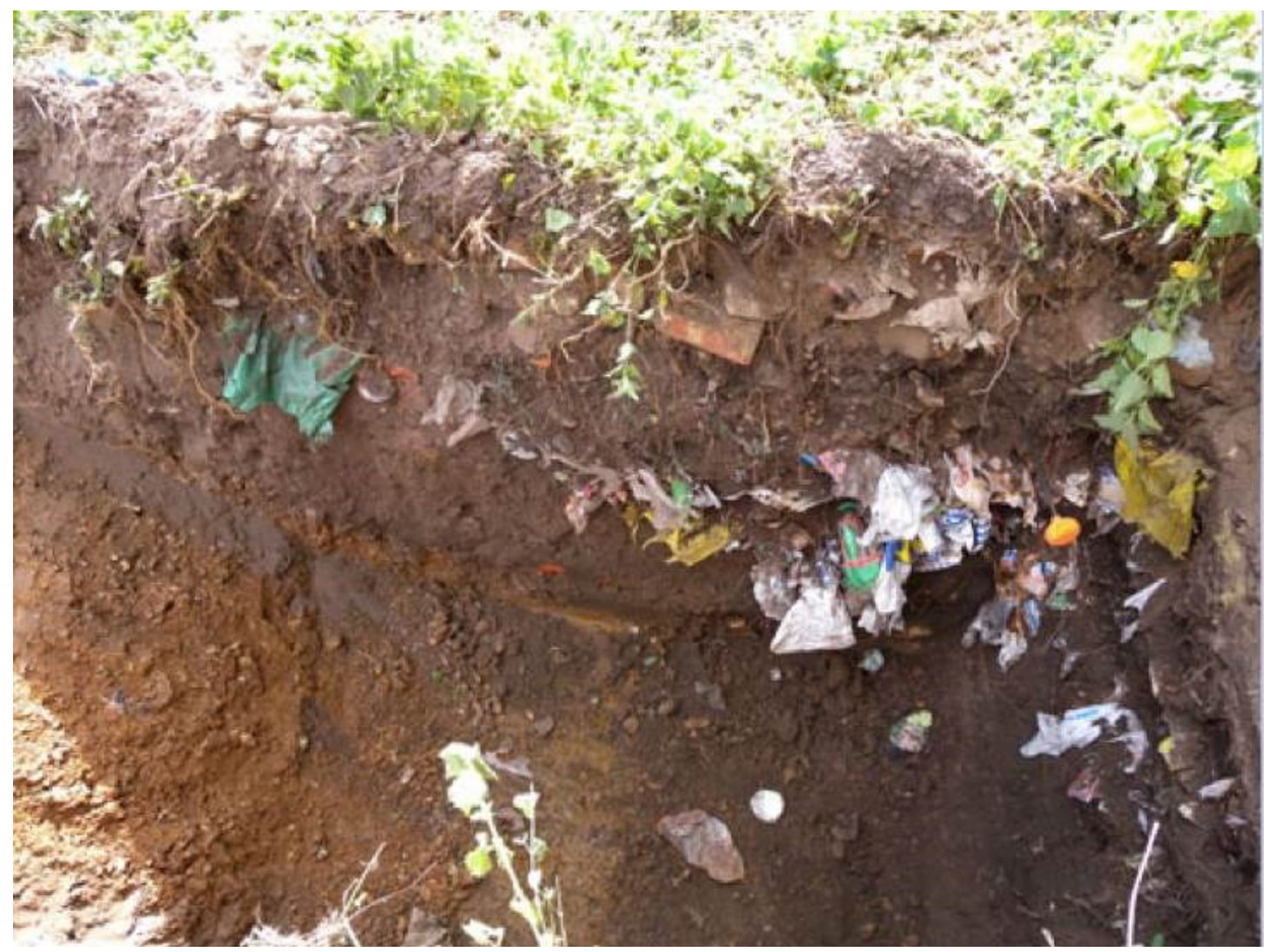

Fig. 7. 1980s plastic bags in the upper fill of an ornamental moat in Tudor gardens from evaluation at Cedars Park, Broxbourne, Herts by Museum of London Archaeology, 2010 (imaged reproduced courtesy of MOLA). The plastic in this case has been in the ground for 30 years. It is well preserved, providing a visual and colourful marker in the profile of an archaeological deposit or anthrosol (a completely or nearly complete human-made soil). As a dateable horizon within a stratigraphic sequence, the plastic-bearing layer here provides relative dating for all layers above (1980s or later) and all layers below (1980s or earlier). Its utility as a stratigraphic marker extends to the whole sequence.

\section{Lakes and rivers}

Plastics have been found in freshwater ecosystems (Eerkes-Medrano et al., 2015), such as lakes (e.g. Eriksen et al., 2013; Imhof et al., 2013; Free et al., 2014; Zbyszewski et al., 2014), and rivers, such as the Thames (Morritt et al., 2014), Danube (Lechner et al., 2014) and Yangtze (Zhao et al., 2014). Plastics are likely to be at least as widely distributed in lakes as they are in the oceans (see below). Although their distribution on shorelines and as floating debris on water has locally been determined, as in the Great Lakes of North America, their distribution in lake bottom sediments has only recently been investigated (Corcoran et al., 2015).

Microplastics are introduced to rivers via wind, storm sewers, and wastewater treatment plants; they also host distinct microbial communities (McCormick et al., 2014). However, the low density of the most commonly produced plastics, 
polyethylene and polypropylene, means that a significant proportion stays within or upon the water column and is transported farther downstream or out to lakes and seas (Sadri and Thompson, 2014). The majority of plastic debris is sourced from land. Thus, rivers are conduits for plastics to enter their final sink: the marine or lake realms. For example, in South Wales about $80 \%$ of litter on estuarine beaches comes from rivers (Williams and Simmons, 1996), and near Toronto, Canada, plastic pellets were observed travelling down the Humber River into Lake Ontario (Corcoran et al., 2015).

Plastics often act as sediment baffles in rivers, as does vegetation and wood debris. Along lake shorelines and river banks, microplastics tend to become trapped in organic debris brought in by waves and currents (Zbyszewski et al., 2014; Corcoran et al., 2015). In addition, high-density plastics may accumulate within channel bedload, where mobile plastic elements in the traction carpet may be abraded rapidly (Williams and Simmons, 1996) and reduced to microplastic particles. Between rivers and the sea, mangrove stands can trap plastics (Ivar do Sul et al., 2014).

\section{Nearshore marine}

That macro- and microplastics were entering the seas, and were likely to cause significant environmental impact, was observed from the 1960s in seabird populations (Kenyon and Kridler, 1969; Harper and Fowler, 1987) and from the 1970 s on the sea surface (Carpenter and Smith, 1972). Since then, both the phenomenon itself and study into it have grown markedly, particularly in the last decade (Ivar do Sul and Costa, 2014; Leinfelder, in press). Attention has focused on the impact of ingestion and entanglement on biota, on their distribution within both water and sediments, and on possible toxic effects. Although plastics are generally inert, they can accumulate toxins such as PCBs on their surfaces or release harmful constituents such as bisphenol A as they weather.

The sea is the final resting place for a range of different types of human litter, from glass to metals to building waste, though plastics form the most striking component. Making up some $10 \%$ of all human refuse by weight, plastics are then selectively transported by wind and water to make up $>50 \%$ of marine litter, and locally considerably more (Barnes et al., 2009). A similar selective concentration of certain natural resistant rock types, such as flint and vein quartz, occurs within sedimentary deposits. There have been some studies of physical sorting of plastics, particularly in coastal areas. For instance, Browne et al. (2010) examined the sorting of microplastics within the Tamar estuary near Plymouth, UK, and noted segregation of lighter and more dense microplastics, although no relationship between microplastics and clay particle distribution was observed. Isobe et al. (2014) noted selective transport of mesoplastics ( $~ 5$ $\mathrm{mm}$ ) towards the shore and microplastics towards offshore in the Seto Sea of Japan.

Plastics enter the sea via rivers, from point and diffuse sources along the shoreline and from ships, though such dumping is now in theory banned by 
international shipping regulation (Ryan et al., 2009, Fig. 1). Estimates of plastics currently entering the sea each year range from 6 million tons (UNEP 2009 in Pham et al., 2014) to between 4.8 and 12.7 million metric tons (Jambeck et al., 2015), with the amount predicted to increase by an order of magnitude by 2025 (Jambeck et al., 2015). Differences in source are evident, for example around the UK coastline, with various proportions derived from rivers, fly-tipping, sewage outfalls, ship discharges (Williams and Simmons, 1996) and coastal tourism.

Significant microplastics (38 to 234 particles per cubic meter), have been found frozen in Arctic sea ice, having seemingly been derived from the Pacific Ocean (Obbard et al., 2014). The Arctic is thus a major global sink for these tiny plastic particles. However, melting at current rates could unlock over one trillion pieces of microplastics over the next decade. Rayon was the most common material, much of it from cigarette filters (one cigarette filter tip comprises $\sim 10,000$ fibres) and hygiene products. Other materials included polyester, nylon, polypropylene (PP), polystyrene (PS), acrylic and polyethylene (PE).

Once within the sea, low-density plastics such as polyethylene (PE) and polypropylene (PP) - that together comprise $55 \%$ of output in Europe (PlasticsEurope, 2015) - float in seawater. These low-density plastics can be moved by wind stress and by surface currents, and in this way they encircle the Earth, becoming concentrated in mid-ocean gyres such as the 'Great Pacific Garbage Patch', some thousand kilometres in diameter (Moore et al., 2001; Ryan et al., 2009; Law et al., 2014). There have been widely reported examples of spilled cargoes of such distinctive objects as plastic ducks tracked to reveal marine pathways (e.g. Ebbesmeyer and Scigliano, 2009; Hohn, 2011). Ultimately, plastics may be washed up on far-distant beaches. On Korean beaches, Jang et al. (2014) found that more than half of the plastic material beached had come from the ocean, via long-distance travel, and not from nearby land.

Plastic fragments with densities $>1 \mathrm{gm} / \mathrm{cm}^{3}$, including PVC, sink in seawater. They can then be moved by tidal and storm-driven currents in shallow water, and by various gravity-driven currents (e.g. turbidity and contour currents) in deep water before finally being deposited. However, low-density plastics have also been found in lake-bottom sediments, having been deposited as a result of density increase by mineral fillers during production, or mineral adsorption while in the water column (Corcoran et al., 2015; Corcoran, 2015). It is also being increasingly realized that the transport of plastics through the water column is often mediated biologically (see below) because microbial films rapidly develop on submerged microplastics and change their buoyancy (Lobelle and Cunliffe, 2011).

Studies of plastics in sediment to date have typically focused on the amount and type of plastics present and on their geographical distribution. However, very few investigations include data on the vertical distribution of plastics within the sediment (exceptions include Kusui and Noda, 2003, Ng and Obbard, 2006, Turra et al., 2014; Corcoran et al., 2015). Inferences on such distribution must be made using general sedimentary facies considerations. 
Coastlines and beaches have understandably attracted much attention, given their sensitive status in human society and the high visibility of plastic litter deposited there. The monitoring of beach litter, mostly macroplastic, is typically done by counting items at the surface per unit length (e.g., per $100 \mathrm{~m}$ ) of coastline, and noting such aspects as type, composition, weight and volume. A recent study of Korean beaches (Hong et al., 2014) found 300-1000 items/100 $\mathrm{m}$, including polystyrene fishing buoys, and plastic bags and bottles. Cigarette filter tips are generally the single most common item found in studies of such sort and in beach cleanups. Of the $\sim 6$ trillion cigarettes smoked annually, the filter-bearing tips of over 4 trillion end up as litter each year (Carlozo, 2008).

Plastics are virtually omnipresent in the coastal zone globally, not only in densely populated regions, but also because of long-distance transport to remote areas. Barnes (2005) noted substantial amounts of macroplastics on remote islands. On some islands such as Diego Garcia, hermit crabs have taken to using plastic bottle tops as homes (see also Reed, 2015, p. 32). He also noted a diminishing trend of plastics from equator to pole in the Southern Ocean, although noticeable amounts still reach Antarctic coasts. In Hawaii, accumulations of plastic debris have formed what Corcoran et al. (2014) referred to as 'plastiglomerates' in which melted plastic associated with campfires (Fig. 3) has bonded beach pebbles and sand to form a rock (theoretically the activity of wildfires and volcanic activity could also cause melting). These dense hybrid plastic-sediment materials have good potential for burial and long-term preservation.

Successive surveys have shown that amounts of plastics in coastal sediment have increased through time, broadly mirroring the rise in global production (Ryan et al., 2009; Fig. 8 herein; Claessens et al., 2011). This trend continues: British beaches in 2009 saw record levels of litter, with an average of 2195 items $/ \mathrm{km}$ in a survey of 374 beaches nationwide, compared with 1045 items $/ \mathrm{km}$ in 1994 (Adam, 2009). This trend occurs despite strenuous clean-up efforts by local authorities and volunteer groups, and the activities of beachcombers. Peak levels can be much greater, exceeding 30000 items/km or 'much higher' in beaches in Europe, Asia and South America (Pham et al., 2014 and references therein).
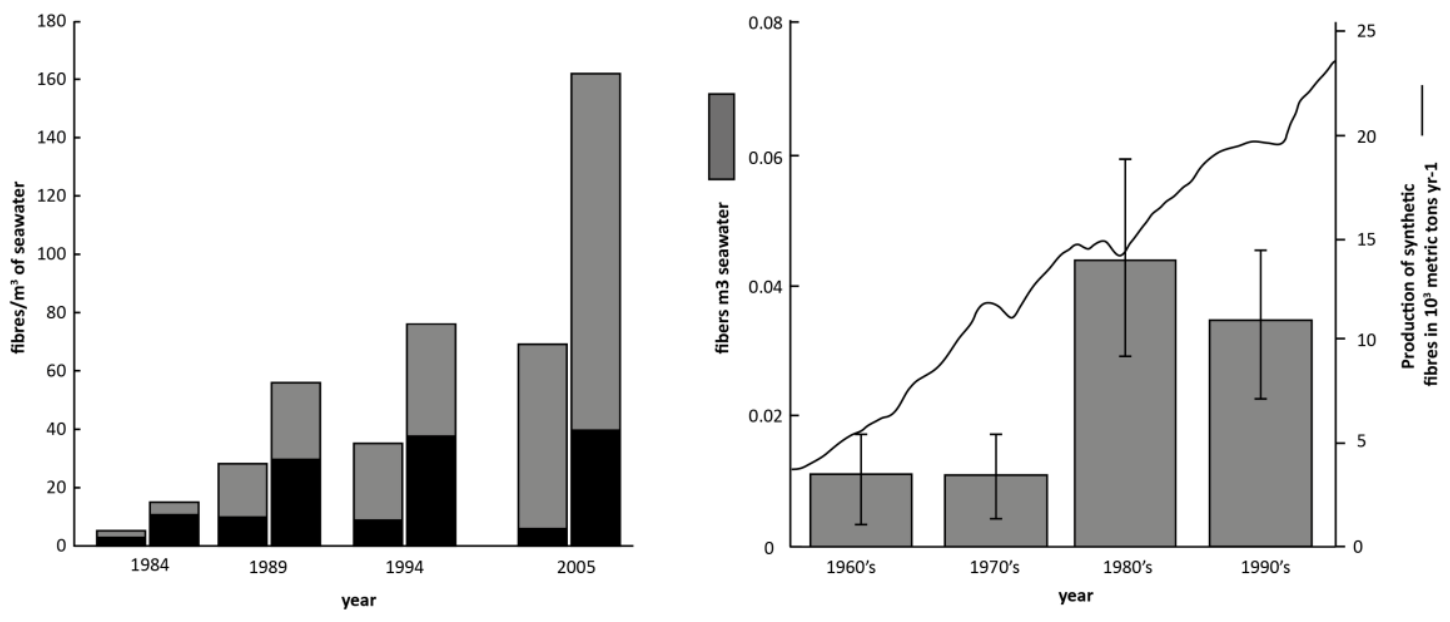
Fig. 8. (Left) increase in number of plastic bottles (left bar) and lids (right bar) on beaches with regular cleaning programmes (in black) or no formal cleaning (in grey), redrawn from Ryan et al. (2009). (Right) Microplastic time series data from Thompson et al. (2004).

In the dynamic beach environment, objects can be buried and exhumed many times (Smith and Markic, 2013). Overall, the few studies (e.g. Turra et al., 2014) involving depth profiles of beaches suggest that plastic items may locally extend downwards for as much as $2 \mathrm{~m}$, with there being an order of magnitude more buried plastic than surface plastic. Hence, there is a sediment body forming in the coastal zone that, if seen in cross-section, could contain sufficient macroplastic material to be recognizable to the field geologist as a post-midtwentieth century deposit (Fig. 9). In some instances, these macroplastic fragments are already visible in beachrock deposits, as in the Basque coast (Irabien et al., 2015).

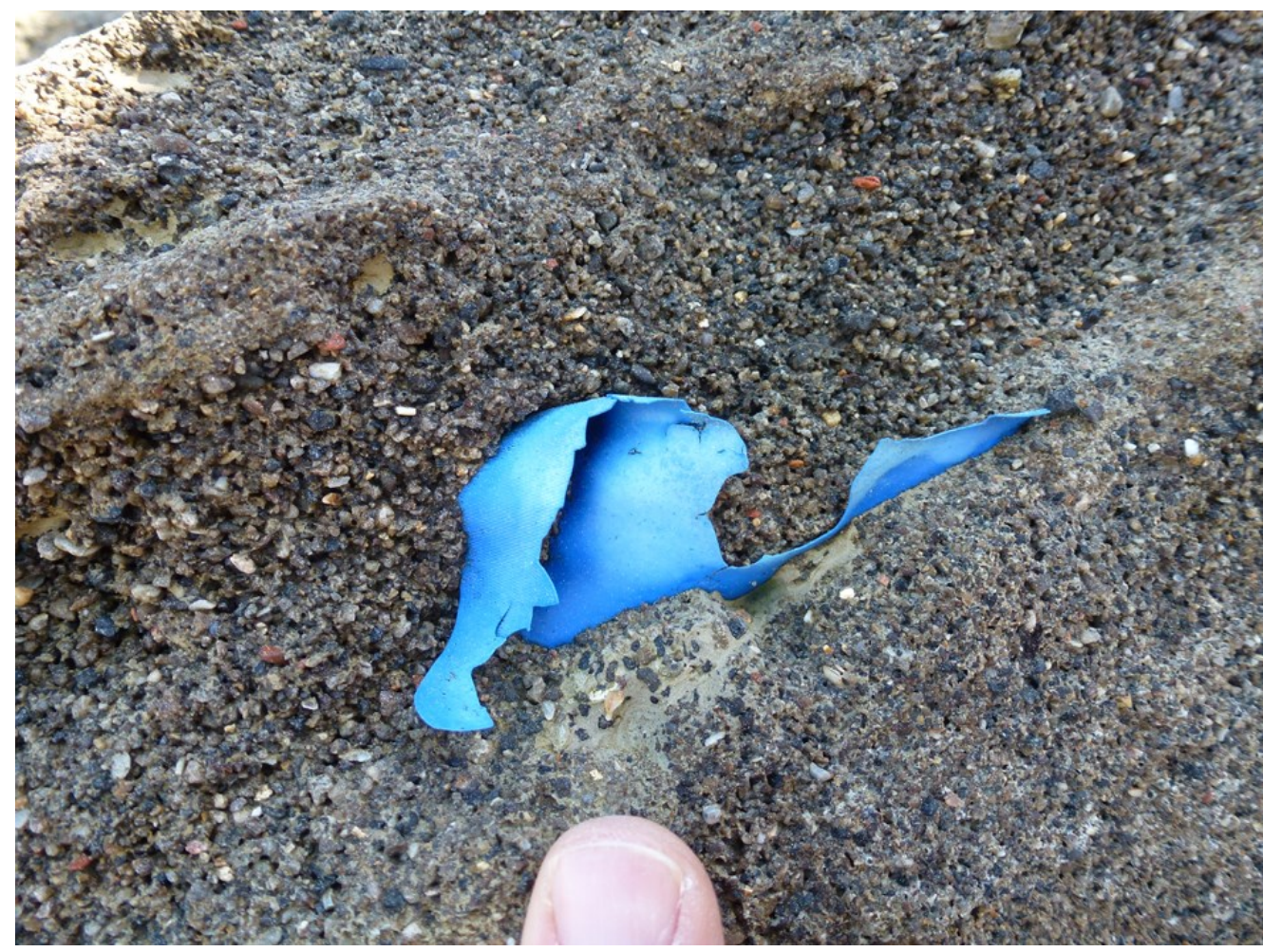

Fig. 9. Plastic fragment in carbonate-cemented beach rock on GorrondatxeAzkorri beach, Basque region, Spain (Photo: H. Astibia).

Such distribution of macroplastics, particularly in remote areas, may be sufficiently sporadic to prevent consistent identification of Anthropocene deposits. An additional complication occurs where winter storms sweep sandy beach deposits out to sea, replenishing them in the spring and summer.

Microplastic particles are more abundant, and more widely and evenly distributed, than are macroplastics, and can be recognized even in samples as small as $50 \mathrm{~g}$ of coastal sediment (Browne et al., 2010, 2011). This can include relatively large particles such as resin pellets, that are near-ubiquitous in some 
beach sediments. Around São Paulo in Brazil, pellets are commonly present at levels of up to $10000 / \mathrm{m}^{3}$ in sediment, and locally of up to $25000 / \mathrm{m}^{3}$ (Turra et al., 2014).

Small microplastics are particularly abundant. Largely composed of microfibres (Fig. 4) detached from machine-washed artificial fabrics (Browne et al., 2011) and transported via sewage outfalls to rivers and dumped sewage sludge, these have become very widely dispersed. Browne et al. (2011) suggested that fibres have become incorporated in, and routinely extractable from, shoreline sediments throughout the world, in quantities that range from tens to hundreds of fibres per litre of sediment (Fig. 10) (Browne et al., 2011; Ivar do Sul and Costa, 2014, Fig. 1). For example, Dekiff et al. (2014) reported 5-25 microplastic particles (mostly microfibres) per kilogram of sediment for Norderney (North Sea), whereas Reis (2014) found an average of 66/kg on the Baltic island of Fehmarn. This potentially provides a near-ubiquitous signature of the Anthropocene in coastal settings.

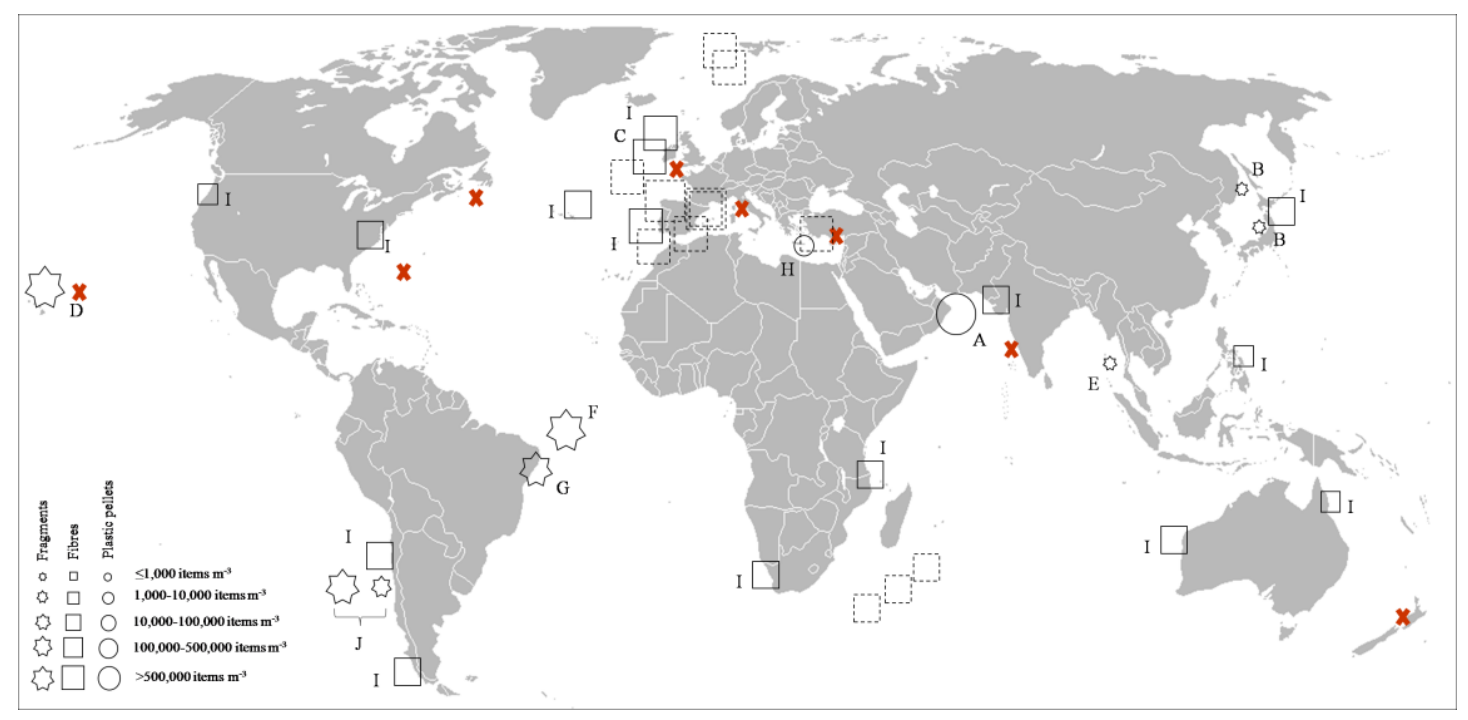

Fig. 10 Reports on the amounts and distribution of microplastics in marine sediment samples. Stars, squares and circles represent the average number of items per cubic metre of sediment available and/or estimated. (A) Khordagui and Abu-Hilal, 1994; (B) Kusui and Noda, 2003; (C) Thompson et al., 2004; (D) McDermid and McMullen, 2004; (E) Ng and Obbard, 2006; (F) Ivar do Sul et al., 2009; (G) Costa et al., 2010; (H) Turner and Holmes, 2011; (I) Browne et al., 2011; (J) Hidalgo-Ruz and Thiel, 2013; (K) Woodall et al., 2014. Dashed squares represent deep-sea sediment core samples. Red crosses represent works that registered microplastics in sediments but did not allow estimation within the scale used here. Extracted and modified from Ivar do Sul and Costa (2014).

\section{Offshore marine}

This encompasses shelf, slope and abyssal sediments, where the extent and stratigraphy of anthropogenic litter has been made clearer by an array of recent studies. Most attention has been gained by the visible plastic debris now floating 
in the water, following the discovery by Moore et al. (2001) of 'the Great Pacific Garbage Patch'. Plastics concentrate in the slowly circulating waters of the North Pacific gyre, with similar concentrations now known to be present in the other great gyres of the world (Law et al., 2014; Fig. 11). The global assessment by Eriksen et al. (2014) showed the scale of the phenomenon: 5 trillion plastic pieces weighing some 250000 tons are now afloat at any one time. They noted one unexpected result - macroplastics made up the great majority of this by weight (ca 85\%). The proportion of microplastics was far less than had been expected (see also Cozar et al., 2014). The ocean gyres show modelled concentrations of surface plastic debris within the mid-latitudes of all oceans (Fig. 11) that mimic atmospheric circulation patterns of radiogenic fallout (e.g. Waters et al., 2015), thus providing a potential dual signature in marine sediments for recognition of the Anthropocene.

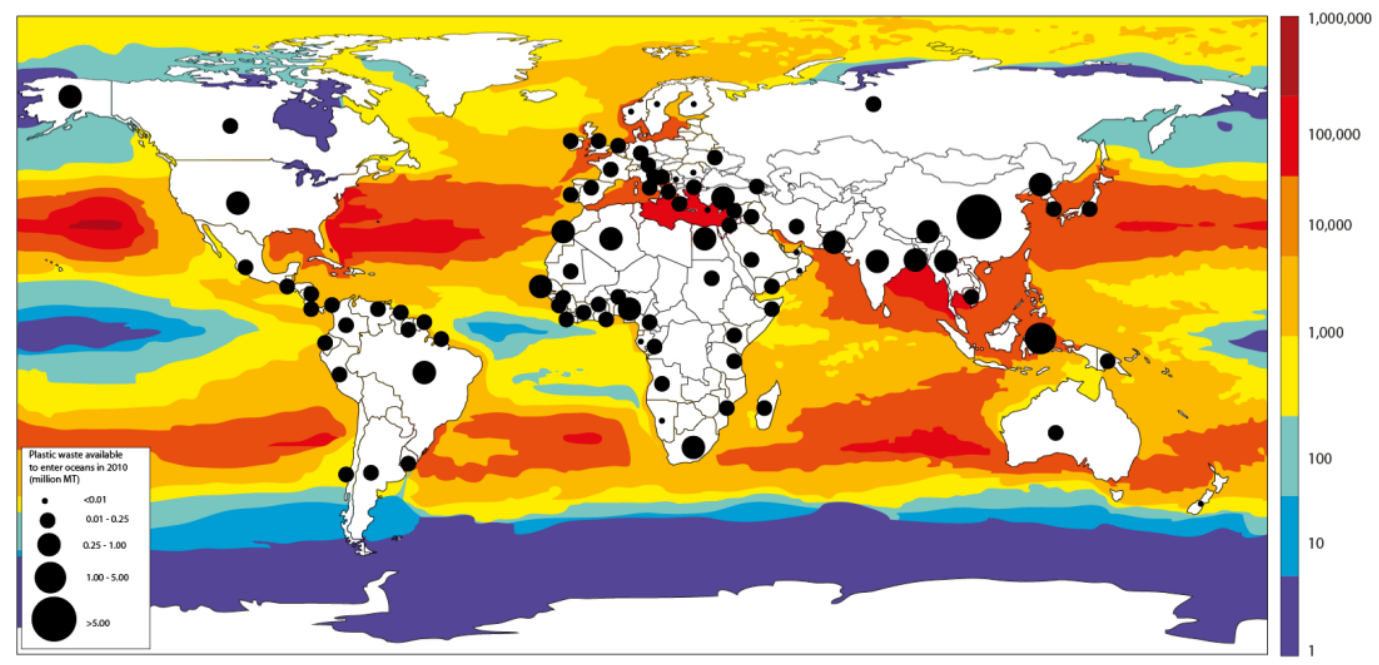

Fig. 11. Modelled distribution of microplastics in ocean surfaces shown by Eriksen et al. (2014, Fig.2) (1mm-<4.75mm). Onshore estimated mass of mismanaged plastic waste is in millions of metric tons, generated by 2010 within $50 \mathrm{~km}$ of the coast (Jambeck et al., 2015).

Zettler et al. (2013) found that most fragments collected from the marine water were of polyethylene and polypropylene, two plastics commonly used in packaging and other single-use applications. This plastic marine debris is colonized by a complex microbial community referred to as the "Plastisphere". Plastisphere communities are distinct from those of surrounding surface water, implying that plastics serve as novel ecological habitats in the open ocean. Microbes may be taking part in the degradation of plastics via physical or metabolic means. Bacteria and fungi are well known to degrade highly refractory 
compounds, including plastic, but this has not yet been demonstrated in the open ocean.

The likely sink for the 'missing surface microplastics' noted above seems be the deep sea. Fischer et al. (2015) discovered microplastics, mainly fibres, at depths of 4869-5766 $\mathrm{m}$ in the Kuril-Kamchatka Trench and adjacent abyssal plain. Even at these great depths, concentrations were as high as $2000 / \mathrm{m}^{2}$. Woodall et al. (2014; see also Goldberg, 1997, and Van Cauwenberghe et al. 2013 for earlier records) examined deep-sea sediment core samples from the sub-polar North Atlantic and North-east Atlantic, the Mediterranean, and seamounts on the SW Indian Ocean. All contained microplastics, mainly as fibres, in abundances ranging from 1.4 to 40 fibres (average 13.4) per $50 \mathrm{ml}$ of sediment (Fig. 10). That was some 4 orders of magnitude more abundant than in the contaminated surface waters above. Even the Indian Ocean seamounts, which showed the lowest abundances, were conservatively calculated to have 4 billion fibres per square kilometre, or $4000 / \mathrm{m}^{2}$ (Woodall et al., 2014).

How did the plastics get to these ocean floors, far distant from land? The fibres were mostly composed of acrylic and polyester, which are denser than seawater. These, it was suggested, may have behaved like fine clay particles, slowly drifting in storm- or turbidity current-generated nepheloid plumes, or carried by thermohaline currents. There were low-density microplastics, too, that had sunk to the ocean floor. These could have been ingested by zooplankton and ejected as faecal pellets, or sank with the plankton when they died, or travelled within the faeces or bodies of fish that ate the zooplankton (Boerger et al., 2010; Cole et al., 2013; Setälä et al., 2014). The microplastics could also have been caught up in gelatinous marine snow. In this respect, microplastics behave in a similar way to other microplanktonic taxa preserved in the geological record (e.g. coccoliths in deep-sea oozes), and represent a primary tool of biostratigraphical correlation in the geological record because of a widespread distribution within strata that are likely preservable long into the future.

Other surveys have shown the spread of larger plastic fragments, by dredging or by remotely operated underwater vehicle (ROV) cameras. Bottles, plastic bags and abandoned fishing nets are abundant (Watters et al., 2010; Richards and Beger, 2011; Tubau et al., 2015; Corcoran, 2015 and references therein), and are often concentrated by topography or currents into submarine lows, such as the bottoms of submarine canyons (Schlining et al., 2013; Tubau et al., 2015). The study by Tubau et al. (2015), of the seabed at 24 of 26 ROV dive sites in the submarine canyons of the NW Mediterranean at depths of 140-1731 m, showed that plastics were the dominant component of litter (72\%). Most of the litter was observed on canyon floors at depths over $1000 \mathrm{~m}$, and may have been carried there by down-slope flows originating near shore. Litter density ranged up to 11.8 items per $100 \mathrm{~m}$ survey line, and averaged between 8,000-15,000 items $/ \mathrm{km}^{2}$, reaching a maximum of 167,540 litter items $/ \mathrm{km}^{2}$ at one site (Tubau et al., 2015). Pham et al. (2014) considered that the relative scarcity of macroplastic objects on shelves was because they were being current-swept into deep water, particularly via submarine canyons. Such deeper water and submarine canyon environments, being less disturbed by bottom trawling than 
are shelf sediments, may provide a good record of the history of plastics influx associated with the Anthropocene. This new plastic-dominated debris layer overlies the debris of previous centuries. Overall, this earlier material is sparser, but a notable component is clinker from the old coal-fired steamships, thrown overboard en route and hence forming 'pavements' below the sailing routes (Ramirez-Llodra et al., 2011).

Thus, in both shoreline and offshore sediments, there is a near-ubiquitous distribution of microplastic fibres, invisible to the naked eye though sufficiently abundant to be extractable from most sediment samples, together with scattered macroplastics. The number of items vary, but, for example, Pham et al. (2014) used submersible cameras to analyse visible debris (mostly plastic) in the northeast Atlantic off Europe. Debris was found everywhere, as far as the Mid-Atlantic Ridge, with densities ranging from $\sim 100-300$ objects $/ \mathrm{km}^{2}$ in continental shelf areas, to $200-600$ objects $/ \mathrm{km}^{2}$ on continental slopes and ocean ridges, to $400-$ 700 objects $/ \mathrm{km}^{2}$ on submarine banks and mounds, to $600-1200$ objects $/ \mathrm{km}^{2}$ in submarine canyons. In addition, the Argo profiling float programme was developed to sow the ocean with 3000 floats to record the temperature and salinity of the ocean down to depths of $2000 \mathrm{~m}$. The programme is intended to operate indefinitely, and will provide further 'scientific litter' comprising the metre-long plastic housings of the floats when they sink to the ocean bed after their batteries die at the end of an approximately 4-year lifetime (www.argo.ucsd.edu/; http://en.wikipedia.org/wiki/Argo_(oceanography).

\section{Preservation potential of plastics in the geological record}

The geological longevity of plastic polymers is poorly known, mainly because these are novel materials that have been in the environment for only decades. Will such plastics still be recognizable over geological timescales? Degradation of plastics may take place chemically, by modification of the molecular structure, or physically or biologically (Kay and Blond, 2005; Shah et al., 2008). Chemical degradation can result from alteration of molecular bonds through chemical reactions driven by heat or solar radiation, or via hydrolysis at very high or very low $\mathrm{pH}$. Physical degradation includes partial or total extraction of additives (e.g. pigments, plasticizers and fillers), the action of solvents and environmental stress-cracking. Biological degradation by bacteria and fungi occurs following depolymerization of plastic by other physical or chemical processes.

Plastics are clearly long-lived on human time-scales, especially when buried and beyond the reach of the ultra-violet light present in sunlight that can break bonds in their chemical structure, causing the plastics to become brittle and then fragment (photodegradation) (Shah et al., 2008). Most fragmentation occurs through photodegradation, mainly in beach environments.

Plastics as a whole are resistant to microbial attack, and this underlies a good deal of their practical utility and of their longevity in the environment.

Nevertheless, some evidence of digestion by microbes has locally been observed (Harshvardan and Jha, 2013; Yang et al., 2014; see also Kasirajan and Ngouajio, 
2012), and plastics may host microbial communities different to the generally ambient ones (McCormick et al., 2014). The sudden appearance of plastics as a widespread new addition to the surface environment, together with the rapid evolutionary rates observed in microbes subject to strong selective pressures, suggests that microbial degradation may become more common over time, not least because any microbes that can use plastics as a food source will be selectively advantaged. Nevertheless, this is currently a minor factor - and it must be noted that many eminently digestible and decomposable organic tissues (shell because of its organic matrix; bone; wood) may be commonly fossilized once buried. However, in common with shells, plastic items may be fossilized in 'cast' and 'imprint' form even if all the original material is lost through biodegradation. Thus the outlines of biros, plastic bottles or compact disks (CDs) may be found as fossils in sedimentary rock in the future even if the plastic itself has degraded or been replaced by other materials.

Colder temperatures within the deep ocean, associated with a lack of UV light, make plastics on the sea-bed more likely to be preserved. In these conditions, they are said to last for 'centuries to millennia' (Gregory and Andrady, 2003), mostly via inference from short-period laboratory studies. Over longer timescales, their diagenesis and fossilization potential once buried in strata is a topic of considerable academic interest, although of no analytical study yet, as far as we are aware. The nearest comparison is with the long-chain polymers in recalcitrant organic fossils such as wood, spores and graptolites. These fossilize by the loss of part of the material, expelled as hydrocarbon liquid or gas, to leave a carbonized husk and, depending on the size and rigidity of the fossil and the nature of the enclosing fossil, also an impression (an external mould). On preliminary consideration, it seems that many plastics will behave similarly over geological timescales. The hydrocarbons released during diagenesis might contribute to future oil and gas deposits.

\section{Discussion}

Plastic debris is widely distributed on land and in the sea. On the land surface, the locally abundant but highly heterogeneous distribution of plastics seems imprecisely described by scientific study. There is, though, considerable potential for plastics to be recorded in archaeological excavations, by a minor adjustment of existing methodologies. And, in developed countries where landfill sites have been categorized, mapped and dated, as in the UK, concentrations of plastic-rich (i.e. 10\%) anthropogenic deposits, metres to tens of metres thick, may be delineated.

In the coastal realm, the accessibility and relative ease of study of environments such as beaches has encouraged more systematic study, and plastic debris has been found to be common along shorelines. It is clear, too, that plastics are widely distributed, both as macroplastics and as microplastics, across the sea floor in most parts of the world (Browne et al., 2011; Woodall et al., 2014; Corcoran, 2015). Overall, therefore, plastics, and particularly microplastics, 
seem to provide an effective signal for recognizing terrestrial and marine sediments deposited since the mid-20th century.

There is a need, though, for more precise study of the use of plastics as stratigraphic indicators. We note that the distribution of plastics is unlike that of artificial radionuclides, where the test bomb-related signal has an abrupt base in about 1952 (Hancock et al., 2014; Zalasiewicz et al., 2015; Waters et al., 2015), reaches peaks in the mid-1960s, then tails off. In contrast, the plastics signal grows more gradually through time and is less evenly distributed across space. We envisage sporadic appearances in the stratigraphic record of some early forms of plastic, notably bakelite and rayon, from the early $20^{\text {th }}$ century, mostly confined close to urban areas in Europe and North America. This putative, localized fore-runner plastics signal (still to be constrained by stratigraphic study) then gives way in the mid-20 th century to a more widespread signal of plastics dispersal, increasing from scarcely perceptible to clearly obvious over little more than half a century (cf. Fig. 2). For instance, a significant presence of plastics within landfill sites on land was not apparent until the early 1970s in developed countries, and displayed some regional diachroneity over the subsequent decade or so as plastics became a global commodity.

In the marine environment, recognition of plastics as an environmental problem did not surface until the late 1960s. Over subsequent decades, the evidence base has become larger while the volume of plastics entering the marine environment has grown exponentially. Thus, the transport of plastics by organisms (and vice versa, in considering floating plastic as vectors for encrusting species) has been well studied, including the ingestion/entanglement (often fatal) by fish and larger vertebrates (e.g. Gregory, 2009). Such specific studies have led to more general relations between filter-feeding plankton, benthic organisms and microplastics (Browne et al., 2008; Cole et al., 2013) being analysed (Ivar do Sul and Costa, 2014).

Little research has been carried out to recognize the extent of the marine plastic signature in the 1940s and 1950s during the early years of its usage and before its environmental impact was realized. That slow beginning makes defining (or precisely locating) the base of the Anthropocene on the basis of plastic materials sensu lato impractical, although plastics are clearly an effective identifier of Anthropocene strata. However, the many forms of plastic developed at different times may be used as time-specific species indicators (Albus et al., 2006) (Fig. 2). For example, acrylic fibres were first created by DuPont in 1941, but not produced in large quantities until the 1950s. This is similar to the stratigraphic use of artificial radionuclides, the onset of signatures for different isotopes being at different times (Waters et al., 2015).

Over geological timescales, the plastics buried in landfill sites may be in part a 'time-bomb' of plastic release. Some landfills, in low ground in tectonically subsiding areas, will simply be buried by more strata, to be fossilized as palaeontological middens. Where landfills are eroded, though, they will begin releasing their debris, including plastic, into the sedimentary cycle (see below). 
Virtually all plastics are moulded into artefacts of many different kinds, each of which in this context may be regarded as a technofossil (Zalasiewicz et al., 2014), which is a trace fossil produced by humans. Technofossils show extremely rapid evolution, entirely detached from the evolution of the trace-making organism (i.e. of humans), and hence the appearance of the different artefacts can mark a fine chronology. - even to the day, as seen in the date-stamping of plastic food wrapping. This character of litter has been used to precisely date extreme flood events affecting the Oman coast (Hoffmann and Reicherter, 2014). Although it is important to recognize the distinction between production date and the timing of accumulation, which may be months or years later, this is still a resolution of dating rarely available to geologists.

Spatially, plastics need to be considered as sedimentary particles contained within 3-dimensional sedimentary bodies (sometimes termed 'lithosomes') that have been shaped by a variety of physical and chemical processes. In the Anthropocene, of course, these sedimentary bodies are still accumulating. Such factors as sedimentation rate, transport paths, sedimentary sorting and biological influence become important. Foci of anthropogenically-influenced sediment input, such as large-river delta-front estuaries, already identified as sensitive recorders of other kinds of human-driven perturbation (Bianchi and Allison, 2009), would merit particular study. In drawing up some preliminary patterns of plastic distribution in the context of sedimentology, one might suggest the following as components of a predictive model to be tested and further developed (Fig. 12):

The dynamic coastal zone will often have a relatively thick (metres-scale) plasticbearing sediment body. Plastic levels can be very high in populated areas and lower, but often still measurable, in uninhabited areas because of long-distance transport. In zones of wave/current reworking, such as beaches, the plasticsbearing sediment body may be locally sharp-based and show internal variations reflecting selective transport and sedimentary sorting, with attrition and enhanced photodegradation of plastic particles prior to burial. In depositional areas, such as deltas and estuaries, where sediment buildup dominates, plastics have preservation potential and may show a stratigraphic pattern of upward increase in relative abundance, reflecting historic increase in plastic production and release. Individual high energy-events, such as storms (Hoffman and Reicherter, 2014) and tsunamis, may sweep plastic debris far inland. In carbonate-producing environments, plastics have been observed in beach rock (Cara Lauria, pers. comm.; Irabien et al., 2015) and may provide nucleation points for microbial carbonate precipitation. 


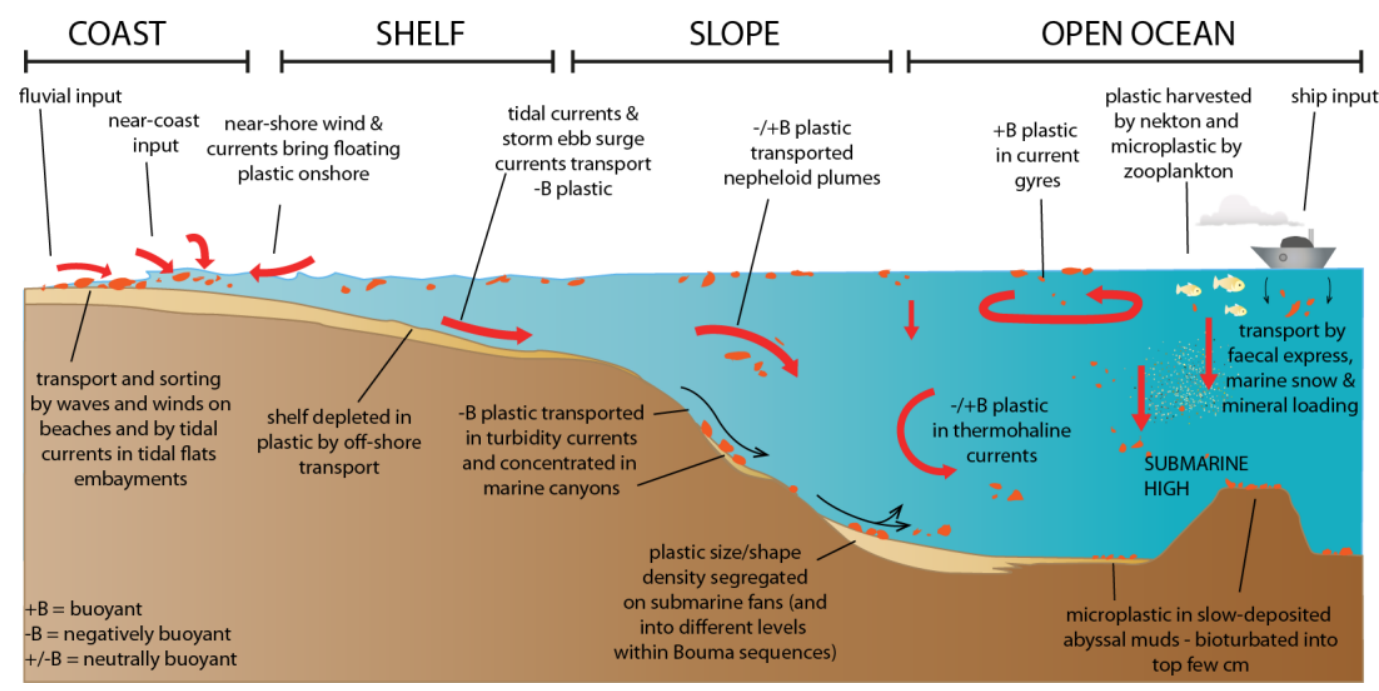

Fig. 12. Conceptual model of plastics transport through and accumulation in the marine realm.

On continental shelves, there may be continuously current-swept areas such as parts of the tidal North Sea, where sediment is swept along in shelly sand dunes. Only the denser plastic fragments might be incorporated there, while lighter or smaller, but still negatively buoyant particles such as fibres might be winnowed out to travel further. On quieter or more distal shelves, plastics may travel with debris in storm ebb surges (or the ebb currents from tsunamis) to be deposited as tempestite layers.

Along continental slopes, plastics will be funneled together with sediment through submarine canyons, as already observed (e.g. Pham et al., 2014). Within canyons, there is likely to be size/shape/density sorting of the plastic debris, as there is of the accompanying sediment. Much of the plastic, especially the microplastic, will be transported through the canyons to end up deposited within turbidite layers covering the surface of submarine fans that extend seawards from the canyons. These turbidite layers will show size/shape density sorting of plastic fragments, comparable to that seen in different fossils in ancient turbidites (for example, robust shell fragments typically end up in the bottom, Bouma A-B divisions of turbidite layers while the less dense fossils are typically concentrated a little higher, in the ripple-laminated Bouma C division: Davies et al., 1997). We expect plastic fragments to behave similarly, and to be concentrated in the upper, C-E divisions, depending on their size, shape and density. Over the course of the Anthropocene, these turbidites, and the tempestite layers noted above, are likely to be of thin (centimetres to decimetres) but of wide extent. Plastics content will reflect the density and behavior of human populations (hence littering potential) along the terrestrial rivers and coast upstream of the canyon. Plastics are likely to show good preservation potential in these settings.

Beyond the turbidite fans there are the pelagic realms of the ocean floor, in part analysed by Woodall et al. (2014). There, sedimentation rates are low and the Anthropocene will be represented by millimetres in stratigraphic thickness, if 
that, and so the plastics may represent a significant part of the input. Most of the sea floor is oxygenated and burrowed (bioturbated) by benthic organisms.

Therefore, the plastics, over depths of (normally) a few centimetres will, like the rest of the sediment, be mixed in with older deposits, and separated from them by a diffuse gradational boundary. This is one of the practical problems of applying chronostratigraphy over very short time intervals (Zalasiewicz et al., 2007). Bioturbation will in effect blur the boundary; but, for practicality's sake, the whole plastic-bearing bioturbated unit might be regarded as Anthropocene.

The preservation potential for the plastic material, as for any other organic compound, will probably increase strongly under dysaerobic or anaerobic conditions. "Dead zones" of coastal and open marine bottom waters will likely become more frequent and more widespread in the Anthropocene, owing to increasing land-derived anthropogenic nutrient runoff, as well as more frequent surface water stratification caused by warming seas (cf. Gruber, 2011; Keeling et al., 2010). In such settings, plastic material might remain preserved in poorly oxygenated sediments over geological timescales. In contrast, in the more aerated, carbonate-supersaturated marine settings of tropical lagoons, plastics are likely to become initially incorporated within early cemented sediment layers. If the plastic fragments then degrade or become fragmented after a few hundred years, there would result a new type of highly porous, vuggy limestone with voids or pseudomorphs mirroring the shape of leached plastic technofossils.

Some contemporary sedimentary units may still remain effectively plastic-free. Whereas beaches in Antarctica have become polluted with plastic, the fringing deeper-water sediments derived from the melting of rock debris-laden glaciers should be pristine, as should remote land-based ice-masses. Perhaps similarly, the contourite drifts that mantle the base of the eastern North American continental slope, derived from deep south-flowing currents from the Arctic Circle, may be largely plastic-free. In volcanic settings, hot primary pyroclastic flows are unlikely to preserve plastics, but the low-temperature lahar deposits derived from them, if they flow through populated areas, will pick up and entomb plastics on the way.

Tsunamis, too, will generate an unsorted mass of materials that, if sourced from urban areas, can entrain a significant amount of plastics. Large amounts of plastic transported in this way may be carried inland along coastal zones, to form perched deposits. Alternatively, these materials may be carried back out to the ocean as a chaotic backflow of poorly-sorted plastic-bearing sediment. Once identified, such tsunami deposits could also be used as time-specific stratigraphic indicators. In the case of the Boxing Day 2004 tsunami, existing wastes in landfill sites were also transported out to sea, (e.g. in Banda Aceh http://www.gdrc.org/uem/disasters/disenvi/tsunami.html).

\section{Conclusions}


There is a growing abundance of plastics in the surface environment. These materials may be considered not only as environmental pollutants, but also as contributors to the character of recent (generally post mid- $20^{\text {th }}$ century) and contemporary strata.

Plastics are now widely enough distributed to characterize such strata over large parts of the world, even in remote environments such as that of the deep sea floor and the polar regions. Especially in marine sediments, microplastics form superficially invisible, but potentially widespread markers, directly akin to microfossils in more conventional palaeontology.

It can be reasonably assumed, from the few studies carried out to date, that the patterns of distribution of plastics as both large and small particles provide a means of characterizing global sedimentary systems by age. Once accumulated within sedimentary strata, plastic particles are likely to have a variable but generally good preservation potential, comparable to that of recalcitrant organic fossils. Plastics are already present in sufficient numbers to be considered as one of the most important types of 'technofossil' that will form a permanent record of human presence on Earth.

Stratigraphically, plastics within sediments comprise a good practical indicator of Anthropocene strata, using a mid-20 th century beginning for this postulated epoch. Recognizing the exponential growth of plastics production since WWII, the onset of this marker of the Anthropocene is likely to be diffuse and not perfectly isochronous in stratigraphic successions. For instance, a significant presence of plastics in the marine and terrestrial environments was not recorded until the late 1960s to early 1970s. Therefore, despite their utility for practical stratigraphy- namely recogition and characterization of Anthropocene deposits plastics cannot be expected to act as a primary marker for precisely defining the start of the Anthropocene. Their correlation potential, though, now stretches out into space, as they have now been carried across the solar system by spacecraft, and placed in orbit around the Earth and on the surface of the Moon and Mars.

Acknowledgements: We thank Deodato Tapete for comments on an earlier version of this manuscript. Colin Waters publishes with the permission of the Exectutive Director, British Geological Survey, Natural Environment Research Council, funded with the support of the British Geological Survey's Engineering Geology science programme. We would like to thank two anonymous referees for comments that have improved the text.

\section{References}

Adam, D. 2009. British beach litter levels highest on record. The Guardian, 8 April 2009. http://www.theguardian.com/environment/2009/apr/08/beachlitter-record-levels-mcs

Albus, S., Bonten, C., Kebler, K., Rossi G., Wessel T. 2006. Plastic Art - A Precarious Success Story. Germany: The AXA Art Conservation Project. 
Andrady, A.L., Neal, M.A., 2009. Applications and societal benefits of plastics. Philos. Trans. R. Soc. B364, 1977-1984.

Barnes, D.K.A., 2005. Remote islands reveal rapid rise of Southern Hemisphere sea debris. Directions in Science 5, 915-921.

Barnes, D.K.A., Galgani, F., Thompson, R.C., Barlaz, M., 2009. Accumulation and fragmentation of plastic debris in global environments. Philos. Trans. R. Soc. B364, 1985-1998.

Barnosky, A.D., 2014. Palaeontological evidence for defining the Anthropocene. In: Waters, C.N., Zalasiewicz, J., Williams, M. Ellis, M.A., Snelling, A. (Eds.) A Stratigraphical Basis for the Anthropocene. Geol. Soc., Lond., Spec. Publ., 395, 149-165.

Besseling, E., Wang, B., Lürling, M., Koelmans, A.A., 2014. Nanoplastic affects growth of S. obliquus and reproduction of D. magna. Environ. Sci. Technol. 48, 12336-12343.

Bianchi, T.S., Allison, M.A., 2009. Large-river delta-front estuaries as natural "recorders" of global environmental change. PNAS 106, 8085-8092.

Boerger, C.M., Lattin, G.L., Moore, S.L., Moore, C.J. 2010. Plastic ingestion by planktivorous fishes in the North Pacific Central Gyre. Mar. Pollut. Bull. 60, 22752278. (doi:10.1016/j.marpolbul.2010.08.007)

Bridgewater, A.V., 1986. Refuse composition projections and recycling technology. Resour. Conserv. 12, 159-174. (doi:10.1016/0166-3097(86)900088)

Browne, M.A., Crump, P., Niven, S.J., Teuten, E.L., Tonkin, A., Galloway, T., Thompson, R.C., 2011. Accumulation of microplastic on shorelines worldwide: sources and sinks. Environ. Sci. Technol. 45, 9175-9179.

Browne, M.A., Dissanayake, A., Galloway, T.S., Lowe, D.M. Thompson, R.C. 2008. Ingested microscopic plastic translocates to the circulatory system of the mussel, Mytilus edulis (L.). Environ. Sci. Technol. 42(13), 5026-5031.

Browne, M.A., Galloway, T.S., Thompson, R.C., 2010. Spatial patterns of plastic debris along estuarine shorelines. Environ. Sci. Technol. 44, 3404-3409.

Carlozo, L.R., (2008) Kicking butts. Chicago Tribune, June 18, 2008. http://articles.chicagotribune.com/2008-0618/features/0806170174 1 cigarette-butts-secondhand-beach-house/2

Carpenter, E.J., Smith, K.L., 1972. Plastics on the Sargasso Sea surface. Science $175,1240-1241$.

Claessens, M., Meester, S.D., Landuyt, L.V. Clerck, K.D., Janssen, C.R., 2011. 
Occurrence and distribution of microplastics in marine sediments along the Belgian coast. Mar. Pollut. Bull. 62, 2199-2204.

Cole, M., Lindeque, P., Fileman, E., Halsband, C., Goodhead, R., Moger, J., Galloway, T.S., 2013. Microplastic ingestion by zooplankton. Environ. Sci. Technol. 47, 6646-6655.

Corcoran, P.L., 2015. Benthic plastic debris in marine and fresh water environments. Envir. Sci. Proc. Impacts (doi: 10.1039/C5EM00188A)

Corcoran, P.L., Moore, C.J., Jazvac, K., 2014. An anthropogenic marker horizon in the rock record. Geol. Soc. Am. Today 24 (6), 4-8.

Corcoran, P.L., Norris, T., Ceccanese, T., Walzak, M.J., Helm, P.A., Marvin, C.H., 2015. Hidden plastics of Lake Ontario, Canada and their potential preservation in the sediment record. Envir. Poll. 204, 17-25.

Costa, M,F, Ivar do Sul, J.A., Silva-Cavalcanti, J.S., Araújo, M.C.B., Spengler, Â., Tourinho, P.S. 2010. On the importance of size of plastic fragments and pellets on the strandline: a snapshot of a Brazilian beach. Environ. Monit. Assess. 168(1-4), 299-304.

Cozar, A., Echevarria, F., González-Gordillo, J.I., Irigoien, X., Úbeda, B, HernándezLeón, S., Palma, Á.T., Navarro, S., García-de-Lomas, J., Ruiz, A.,

Fernández-de-Puelles, M.L., Duarte, C.M., 2014. Plastic debris in the open ocean. P. Natl. Acad. Sci. USA 111, 10 239-10 244.

Crutzen, P.J., 2002. Geology of Mankind. Nature 415, 23.

Crutzen, P.J., Stoermer, E.F., 2000. The "Anthropocene". Global Change Newsl. 41, 17-18.

Davies, J.R., Fletcher, C.J.N., Waters, R.A., Wilson, D., 1997. Geology of the country around Llanilar and Rhayader. Memoir of the British Geological Survey, Sheets $178 \& 179$ (England and Wales), xii + 267 pp.

Debrot, A.O., Vinke, E., van der Wende, G.,Hylkema, A., Reed, J.K., 2014.

Deepwater marine litter densities and composition from submersible videotransects around the ABC-islands, Dutch Caribbean. Mar. Pollut. Bull. 88: 361365.

Dekiff, J.H., Remy, D., Kasmeier, J., Fries, E. 2014. Occurrence and spatial distribution of microplastics in sediments from Norderney. Environ. Pollut. 186, 248-256.

Della Torre, C., Bergami, E., Salvati, A. Faleri, C., Cirino, P., Dawson, K.A., Corsi, I 2014. Accumulation and embryotoxicity of polystyrene nanoparticles at early stage of development of sea urchin embryos Paracentrotus lividus. Environ. Sci. Technol. 48, 12302-12311. 
Driedger, A.G.J., Dürr, H.H., Mitchell, K., Van Cappellen, P., 2015. Plastic debris in the Laurentian Great Lakes: A review. J. Great Lakes Res. 41, 9-19.

Ebbesmeyer, C., Scigliano, E. 2009. Flotsametrics and the Floating World: How One Man's Obsession with Runaway Sneakers and Rubber Ducks Revolutionized Ocean Science. London: Collins. pp.304 ISBN 9780061558412.

Edgeworth, M., Richter, D.DeB., Waters, C.N., Haff, P, Neal, C., Price, S.J. 2015. Diachronous beginnings of the Anthropocene: The lower bounding surface of anthropogenic deposits. Anthropocene Rev. 2(1), 1-26.

Eerkes-Medrano, D., Thompson, R.C., Aldridge, D.C. 2015. Microplastics in freshwater systems: a review of the emerging threats, identification of knowledge gaps and prioritisation of research needs. Water Res. 75, 63-82.

Eriksen, M., Masin, S., Wilson, S., Box, C., Zellers, A., Edwards, W., Farley, H., Amato, S., 2013. Microplastic pollution in surface waters of the Laurentian Great Lakes. Mar. Pollut. Bull. 77, 177-182.

Eriksen M., Lebreton, L.C.M., Carson, H.S. Thiel, M., Moore, C.J., Borerro, J.C. Galgani, F., Ryan, P.G., Reisser, J., 2014. Plastic pollution in the world's oceans: More than 5 trillion pieces weighing over 250000 tons afloat at sea. Plos ONE 9 (12): e111913. (doi:10.1371/journal.pone.0111913).

Fischer, V., Elsner, N.O., Brenke, N., Schwabe, E., Brandt, A., 2015. Plastic pollution of the Kuril-Kamchatka Trench area (NW pacific). Deep Sea Res., Part II, 111, 399-405.

Ford, J.R., Price, S.J., Cooper, A.H., Waters, C.N., 2014. An assessment of lithostratigraphy for anthropogenic deposits. In: Waters, C.N., Zalasiewicz, J., Williams, M., Ellis, M.A., Snelling, A. (Eds.), A Stratigraphical Basis for the Anthropocene. Geol. Soc., Lond., Spec. Publ. 395, 55-89.

Free, C.M., Jensen, O.P., Mason, S.A., Eriksen, M.,Williamson, N.J., Boldgiv, B., 2014. Highlevels of microplastic pollution in a large, remote, mountain lake. Mar. Pollut. Bull. 85, 156-163.

Gasperi, J., Dris, R., Mirande-Bret, C., Mandin, C., Langlois, V., Tassin, B. 2015. First overview of microplastics in indoor and outdoor air. In 15th EuCheMS International Conference on Chemistry and the Environment. https://halenpc.archives-ouvertes.fr/hal-01195546/

Goldberg, E.D., 1997. Plasticizing the seafloor: An overview: Environ. Technol. 18, 195-201..

Gregory, M.R. 2009. Environmental implications of plastic debris in marine settings: Entanglement, ingestion, smothering, hanger-on, hitch-hiking and alien invasions: Philos. Trans. R. Soc. 
Gregory, M.R., Andrady, A.L., 2003. Plastics in the marine environment. In: Andrady, A.L. (Ed) Plastics and the Environment. New Jersey: Wiley \& Sons p. 379-401.

Gruber, N., 2011. Warming up, turning sour, losing breath: ocean biogeochemistry under global change. Philos. Trans. R. Soc. A 369, 1980-1996.

Hancock, G.J., Tims, S.G., Fifield, L.K., Webster, I.T., 2014. The Release and Persistence of Radioactive Anthropogenic Nuclides. In: Waters, C.N., Zalasiewicz, J., and Williams, M., Ellis, M.A., Snelling, A. (Eds.), A Stratigraphical Basis for the Anthropocene. Geol. Soc., Lond., Spec. Publ. 395, 265-281. (doi:

10.1144/SP395.15)

Harshvardhan, K., Jha, B. 2013. Biodegradation of low-density polyethylene by marine bacteria from pelagic waters, Arabian Sea, India. Mar. Pollut. Bull. 77, 100-106. (doi:10.1016/j.marpolbul.2013.10.025)

Harper, P.C., Fowler, J.A., 1987. Plastic pellets in New Zealand storm-killed prions (Pachyptila spp.) 1958-1998. Notornis 34, 65-70.

Hidalgo-Ruz V, Thiel M. 2013. Distribution and abundance of small plastic debris on beaches in the SE Pacific (Chile): A study supported by a citizen science project. Mar. Environ. Res. 87, 12-18.

Hoffmann, G., Reicherter, K. 2014. Reconstructing Anthropocene extreme flood events by using litter deposits. Global Planet. Change 123, 22-28.

Hohn, D., 2011, Moby Duck. Union Books, Aurum Press, London,402pp.

Hong, S., Lee, J., Kang, D., Choi, H-K, Ko, S-H., 2014. Quantities, composition and sources of beach debris in Korea from the results of nationwide monitoring. Mar. Pollut. Bull. 84, 27-34.

Hussain, I. Hamid, H. 2003. Plastics in agriculture. In: Andrady, A,L, (Ed.) Plastics and the environment. Wiley, Hoboken, pp 185-209.

Imhof, H.K., Ivleva, N.P., Schmid, J., Niessner, R., Laforsch, C., 2013. Contamination of beach sediments of a subalpine lake with microplastic particles. Curr. Biol. 23, R867-R868.

Irabien, M.J., García-Artola, A., Cearreta, A., Leorri, E. 2015. Chemostratigraphic and lithostratigraphic signatures of the Anthropocene in estuarine areas from the eastern Cantabrian coast (N. Spain). Quatern. Int. 364, 196-205.

Isobe, A., Kubo, K., Tamura, Y., Kako, S., Nakashima, E., Fujii, N., 2014. Selective transport of microplastics and mesoplastics by drifting in coastal waters. Mar. Pollut. Bull. 89, 324-330. 
Ivar do Sul, J.A., Costa, M.F., 2014. The present and future of microplastic pollution in the marine environment. Environ. Pollut. 185, 352-364.

Ivar do Sul, J.A., Spengler, A., Costa, M., 2009. Here, there and everywhere. Small plastic fragments and pellets on beaches of Fernando de Noronha (Equatorial Western Atlantic). Mar. Pollut. Bull. 58, 1229-1244.

Ivar do Sul, J.A., Costa, M.F., Silva-Cavalcanti, J., Araújo, M.C.B., 2014. Plastic debris retention and exportation by a mangrove forest patch. Mar. Pollut. Bull. $78,252-257$.

Jambeck, J.R., Geyer, R., Wilcox, C., Siegler, T.R., Perryman, M., Andrady, A., Narayan, R, Law, K.L.2015. Plastic waste inputs from land into the ocean. Science 347, 768-771.

Jang. Y.C., Lee, J., Hong, S., Lee, J.S., Shim, W.J., Song, Y.K.2014. Sources of plastic marine debris on beaches of Korea: More from the ocean than the land. Ocean Sci. J. 49(2), 151-162.

Kasirajan, S., Ngouajio, M., 2012. Polyethylene and biodegradable mulches for agricultural applications: a review. Agron. Sustain. Dev. 32(2): 501-529.

Kay, D., Blond, E., 2005. A guide to assess the durability of 'plastic' materials used in civil engineering. $6^{\text {th }}$ Transportation Speciality Conference, Toronto, Canada June 2-4, 2005: TR-189-1-12.

Keeling, R.F., Körtzinger, A., Gruber, N. 2010. Ocean deoxygenation in a warming world. Annual Review of Marine Science 2, 199-229. (doi:

10.1146/annurev.marine.010908.163855)

Kenyon, K.W., Kridler, E., 1969. Layson albatross swallow indigestible matter. Auk 86, 339-343.

Khordagui, H.K., Abu-Hilal, A.H., 1994. Industrial plastic on the southern beaches of the Arabian Gulf and the western beaches of the Gulf of Oman. Environ. Pollut. 84(3), 325-327.

Kusui, T. Noda, M., 2003. International survey on the distribution of stranded and buried litter on beaches along the Sea of Japan. Mar. Pollut. Bull. 47, 175-179.

Law, K.L., Morét-Ferguson, S.E., Goodwin, D.S., Zettler, E.R., DeForce, E., Kukulka, T., Proskurowski, G., 2014. Distribution of surface plastic debris in the Eastern Pacific Ocean from an 11-year data set. Environ. Sci. Technol. 48, 4732-4738.

Lechner, A., Keckeis, H., Lumesberger-Loisl, F., Zens, B., 2014. The Danube so colourful: a potpourri of plastic litter outnumbers fish larvae in Europe's second largest river. Environ. Pollut. 188, 177-181. 
Leinfelder, R. in press. Ozeane. In: Kersten, J. (Ed.) Inwastement. Abfall in Umwelt und Gesellschaft. Transcript-Verlag, Bielefeld, ca. 270 pp.

Lobelle, D., Cunliffe, M., 2011. Early microbial biofilm formation on marine plastic debris. Mar. Poll. Bull. 62, 197-200.

McCormick, A., Hoellin, T.J., Mason, S.A., Schluep, J., Kelly, J.J. 2014. Microplastic is an abundant and distinct microbial habitat in an urban river. Environ.. Sci.. Technol. 48, 11863-11871.

McDermid, K,J,, McMullen, T.L., 2004. Quantitative analysis of small-plastic debris on beaches in the Hawaiian archipelago. Mar. Pollut. Bull. 48(7), 790-794.

Moore, C.J., Moore, S.L., Leecaster, M.K., Weisberg, S.B., 2001. A Comparison of Plastic and Plankton in the North Pacific Central Gyre. Mar. Pollut. Bull. 42 (12), 1297-300.

Morritt, D., Stefanoudis, P.V., Pearce, D. Crimmen, O.A., Clark, P.F.2014. Plastic in the Thames: a river runs through it. Mar. Pollut. Bull. 78, 196-200.

(doi:10.1016/j.marpolbul.2013.10.035)

Muir, D.G.G., Rose, N.L., 2007. Persistent organic pollutants in the sediments of Lochnagar. In: Rose, N.L. (Ed.) Lochnagar, the Natural History of a mountain lake. Developments in Paleoenvironmental Research 12, 375-402. Springer, Dordecht, The Netherlands.

Ng, K.L., Obbard, J.P., 2006. Prevalence of microplastics in Singapore's coastal marine environment. Mar. Pollut. Bull. 52, 761-767.

Nuelle, M-T., Dekiff, J.H., Remy, D., Fries, E., 2014. A new analytical approach for monitoring microplastics in marine sediments. Environ. Pollut. 184, 161-169. (doi:10.1016/j.envpol.2013.07.027)

Obbard, R.W., Sadri, S., Wong, Y.Q., Khitun, A.A., Baker, I., Thompson, R.C., 2014. Global warming releases microplastic legacy frozen in Arctic Sea ice. Earth's Future 2, 315-320.

Pham, C.K., Ramirez-Llodra., E. Alt, C.H.S., Amaro, T., Bergmann, M., Canals, M., Company, J.B., Davies, J., Duineveld, G., Galgani, F., Howell, K.L., Huvenne, V.A.I., Isidro, E., Jones, D.O.B., Lastras, G., Morato, T., Gomes-Pereira, J.N., Purser, A., Stewart, H., Tojeira, I., Tubau, X., Rooij, D.V., Tyler P.A.. 2014. Marine litter density and distribution in European seas, from shelves to deep basins. PLoS ONE 9(4): e95839.

PlasticsEurope (2013) Plastics-the facts 2013: An analysis of European latest plastics production, demand and waste data. Available: www.plasticseurope.de/cust/documentrequest.aspx?DocID559179. 
PlasticsEurope (2015) Plastics-the facts 2014/2015: An analysis of European latest plastics production, demand and waste data. Available:

http://www.plasticseurope.de/cust/documentrequest.aspx?DocID=62506.

Ramirez-Llodra, E., Tyler, P.A., Baker, M.C., Bergstad, O.A., Clark, M.R., Escobar, E., Levin, L.A., Menot, L., Rowden, A.A., Smith, C.R., Van Dover C.L., 2011. Man and the last great wilderness: human impact on the deep sea. PLoS ONE 6, e22588.

Rathje, W. Murphy, C., 1992. Rubbish! The Archaeology of Garbage. HarperCollins, New York, 250 pp.

Reed, C., 2015. Dawn of the Plasticene age. New Scientist 225 (3006, 31 January 2015), 28-32.

Reis, L., 2014. Occurrence of macro- and microplastics in sediments from Fehmarm. BSc. Thesis, Freie Universität, Berlin.

Richards, Z.T., Beger, M. 2011. A quantification of the standing stock of macrodebris in Majuro lagoon and its effect on hard coral communities. Mar. Pollut. Bull. 62, 1693-1701.

Rillig, M.C., 2012. Microplastic in terrestrial ecosystems and the soil? Environ. Sci. Technol. 46, 6453-6454.

Rochman, C., Browne, M.A., Halpern, B. Hentschel, B.T.. Hoh, E., Karapanagioti, H.K.. Rios-Mendoza, L.M.. Takada, H., Teh, S., Thompson, R.C.. 2013. Classify plastic waste as hazardous. Nature 494, 169-171.

Rose, N.L. 2015. Spheroidal carbonaceous fly ash particles provide a globally synchronous stratigraphic marker for the Anthropocene. Environ. Sci. Technol. 49(7), 4155-4162.

Ryan, P.G., Moore, C.J., van Franeker, J.A., Moloney, C.L., 2009. Monitoring the abundance of plastic debris in the marine environment. Philos. Trans. R. Soc. B 364: 1999-2012.

Sadri, S.S., Thompson, R.C., 2014. On the quantity and composition of floating plastic debris entering and leaving the Tamar Estuary, Southwest England. Mar. Pollut. Bull. 81, 55-60.

Schlining, K., von Thun, S., Kuhnz, L. Schlining, B., Lundsten, L., Stout, N.J., Chaney, L., Connor, J. 2013. Debris in the deep: Using a 22-year video annotation database to survey marine litter in Monterey Canyon, central California, USA. Deep-Sea Research Part I: Ocean Research Paper 79, 96-105.

Setälä, O., Fleming-Lehtinen, V. Lehtiniemi, M. 2014. Ingestion and transfer of microplastics in the planktonic food web. Environ. Pollut. 185, 77-83.

(doi:10.1016/j.envpol.2013.10.013) 
Shah, A.A.., Hasan, F., Hameed, A., Ahmed, S., 2008. Biological degradation of plastics: A comprehensive review. Biotechnol. Adv. 26, 246-265.

Smith, S.D.A., Markic, A. 2013. Estimates of Marine Debris Accumulation on Beaches Are Strongly Affected by the Temporal Scale of Sampling. PlosOne 8, 16.

Steffen, W., Crutzen, P.J., McNeill, J.R. 2007. The Anthropocene: Are Humans Now Overwhelming the Great Forces of Nature? Ambio, 36, 614-621.

Steffen, W., Broadgate, W., Deutsch, L. Gaffney, O., Ludwig, C.,2015. The trajectory of the Anthropocene: the Great Acceleration. Anthropocene Rev. 2 (1), 81-98.

Swindles, G.T., Watson, E., Turner, T.E., Galloway, J.M., Hadlari, T., Wheeler, J., Bacon, K.L., 2015. Spheroidal carbonaceous particles are a defining stratigraphic marker for the Anthropocene. Nature Scientific Reports.

Tansel, B. Yildiz, B.S. 2011. Goal-based waste management strategy to reduce persistence of contaminants in leachate at municipal solid waste landfills. Environ. Dev. Sustain. 13, 821-831.

Thompson, R.C., Olsen, Y., Mitchell, R.P. , Davis, A., Rowland, S.J., John, A.W.G., McGonigle, D., Russell, A.E.2004. Lost at sea: where is all the plastic? Science 304, 838.

Thompson, R.C., Moore, C., vom Saal, F.S., Swan, S.H., 2009. Plastics, the environment and human health: current consensus and future trends. Philos. Trans. R. Soc. B 364, 2153-2166.

Tubau, X., Canals, M., Lastras, G. and Rayo, X., 2015. Marine litter on the floor of deep submarine canyons of the Northwestern Mediterranean Sea: The role of hydrodynamic processes. Progress in Oceanography, 134, 379-403.

Tully, J. 2009. A Victorian Ecological Disaster: Imperialism, the Telegraph, and Gutta-Percha, J. World Hist. 20(4), 559-579.

Turner, A. Holmes, L. 2011. Occurrence, distribution and characteristics of beached plastic production pellets on the island of Malta (central Mediterranean). Mar. Pollut. Bull. 62(2), 377-381.

Turra, A., Manzano, A.B., Dias, R.J.S., Mahiques, M.M., Barbosa, L., Balthazar-Silva, D., Moreira, F.T., 2014. Three-dimensional distribution of plastic pellets in sandy beaches: shifting paradigms. Scientific Reports 4, 4435.

Van Cauwenberghe, L., Vanreusel, A., Mees, J., Janssen, C.R., 2013. Microplastic pollution in deep-sea sediments. Environ. Pollut. 182, 495-499. 
Velzboer, I., Kwadijk, C.J.A.F., Koelmans, A.A. 2014. Strong sorption of PCBs to nanoplastics, microplastics, carbon tubules, and fullerenes. Environ. Sci. Technol. 48: 4869-4876.

Waters, C.N., Zalasiewicz, J., Williams, M., Ellis, M.A., Snelling, A. (Eds.), 2014.

A Stratigraphical Basis for the Anthropocene. Geol. Soc., Lond., Spec.

Publ. 395, pp. 321.

Waters, C.N., Syvitski, J.P.M., Gałuszka, A. Hancock, G.J., Zalasiewicz, J., Cearreta, A., Grinevald, J., Jeandel, C., McNeill, J.R., Summerhayes, C., Barnosky, A. (2015) Can nuclear weapons fallout mark the beginning of the Anthropocene Epoch? B. Atom. Sci. 71, 46-57.

Waters, C.N., Zalasiewicz, J., Summerhayes, C., Barnosky, A.D., Poirier, C., Gałuszka, A., Cearreta, A., Edgeworth, M., Ellis, E.C., Ellis, M., Jeandel, C., Leinfelder, R., McNeill, J.R., Richter, D deB., Steffen, W., Syvitski, J., Vidas, D., Wagreich, M., An, Z., Grinevald, J., Odada, E., Oreskes, N. and Wolfe, A.P. 2016, in press. The Anthropocene is functionally and stratigraphically distinct from the Holocene. Science.

Watters, D.L., Yoklavich, M.M. Love, M.S., Schroeder, D.M., 2010. Assessing marine debris in deep seafloor habitats off California. Mar. Pollut. Bull. 60: 131-138.

Wilkinson, I.P., Poirier, C., Head, M.J., Sayer, C.D., Tibby, J., 2014.

Micropalaeontological signatures of the Anthropocene. In: Waters CN, Zalasiewicz J, Williams M Ellis, M.A., Snelling, A. (Eds.) A Stratigraphical Basis for the Anthropocene. Geol. Soc., Lond., Spec. Publ., 395, 185-219.

Williams, A.T., Simmons, S.L. 1996. The degradation of plastic litter in rivers: implications for beaches. J. Coastal Conserv. 2: 63-72.

Williams, M., Zalasiewicz, J., Haywood, A., Ellis, M. 2011. The Anthropocene: a new epoch of geological time. Thematic set of 13 papers in the Philos. Trans. R. Soc., Lond., Series A369: 833-1112.

Woodall, L.C., Sanchez-Vidal, A, Canals, M. Gordon L.J. Paterson, R.C., Sleight, V., Calafat, A., Rogers, A.D., Narayanaswamy, B.E., Thompson, R.C. 2014. The deep sea is a major sink for microplastic debris. Royal Society Open Science 1: 140317.

Yang, J., Yang, Y., Wu, W.M., Zhao, J, Jiang, L. 2014. Evidence of polyethylene biodegradation by bacterial strains from the guts of plastic-eating waxworms. Environ. Sci. Technol. 48(23), 13776-13784.

Zalasiewicz, J. Smith, A., Hounslow, M., Williams, M., Gale, A., Powell, J., Waters, C., Barry, T.L., Bown, P.R., Brenchley, P., Cantrill, D., Gibbard, P., Gregory, F.J., Knox, R., Marshall, J., Oates, M., Rawson, P., Stone, P., Trewin, N.,2007. The scale- 
dependence of strata-time relations: implications for stratigraphic classification. Stratigraphy 4, 139-144.

Zalasiewicz, J., Williams, M., Smith, A., Barry, T.L., Coe, A.L., Bown, P.R., Brenchley, P.,Cantrill, D., Gale, A., Gibbard, P., Gregory, F.J., Hounslow, M., Kerr, A.C., Pearson, P., Knox, R., Powell, J., Waters, C., Marshall, J., Oates, M., Rawson, P., Stone, P., 2008. Are we now living in the Anthropocene? Geol. Soc. Am. Today 18, 4-8.

Zalasiewicz, J., Williams, M., Waters, C.N., Barnosky, A.D., Haff, P., 2014. The technofossil record of humans. Anthropocene Rev. 1, 34-43.

Zalasiewicz J., Waters, C.N., Williams, M., Barnosky, A.D., Cearreta, A., Crutzen, P., Ellis, E., Ellis, M.A., Fairchild, I.J., Grinevald, J., Haff, P.K., Hajdas, I., Leinfelder, R., McNeill, J.R., Odada, E.O., Poirier, C., Richter, D., Steffen, W., Summerhayes, C., Syvitski, J.P.M., Vidas, D., Wagreich, M., Wing, S.L., Wolfe, A.P., Zhisheng An, Oreskes, N. 2015. When did the Anthropocene begin? A mid-twentieth century boundary is stratigraphically optimal. Quatern. Int.. 383, 196-203.

Zbyszewski, M., Corcoran, P.L., Hockin, A., 2014. Comparison of the distribution and degradation of plastic debris along the shorelines of the Great Lakes, North America. J. Gt. Lakes Res. 40, 288-299.

Zettler, E.R., Mincer, T.J., Amaral-Zettler, L.A., 2013. Life in the "Plastisphere": Microbial communities on plastic marine debris. Environ. Sci. Technol. 47, 7137-7146.

Zhao, S., Zhu, L., Wang, T., Li, D. 2014. Suspended microplastics in the surface water of the Yangtze estuary system, China: first observations on occurrence, distribution. Mar. Pollut. Bull. 86, 562-568. 